\title{
SEX AND SCIENCE: \\ HOW PROFESSOR GENDER PERPETUATES THE GENDER GAP
}

\author{
Scott E. Carrell \\ Marianne E. Page \\ James E. West \\ Working Paper 14959 \\ http://www.nber.org/papers/w14959
}

\author{
NATIONAL BUREAU OF ECONOMIC RESEARCH \\ 1050 Massachusetts Avenue \\ Cambridge, MA 02138
}

May 2009

Thanks go to USAFA personnel: J. Putnam, D. Stockburger, R. Schreiner, K. Carson and P. Egleston for assistance in obtaining the data, and to Deb West for data entry. Thanks also go to Charlie Brown, Charles Clotfelter, Caroline Hoxby, Deborah Niemeier, Kim Shauman, Catherine Weinberger and seminar participants at NBER Higher Education Working Group, PPIC, SDSU, UC Davis, UC Irvine, and UC Santa Cruz for their helpful comments and suggestions. The views expressed in this article are those of the authors and do not necessarily reflect the official policy or position of the USAF, DoD, the U.S. Government, or the National Bureau of Economic Research.

NBER working papers are circulated for discussion and comment purposes. They have not been peerreviewed or been subject to the review by the NBER Board of Directors that accompanies official NBER publications.

(C) 2009 by Scott E. Carrell, Marianne E. Page, and James E. West. All rights reserved. Short sections of text, not to exceed two paragraphs, may be quoted without explicit permission provided that full credit, including $\odot$ notice, is given to the source. 
Sex and Science: How Professor Gender Perpetuates the Gender Gap

Scott E. Carrell, Marianne E. Page, and James E. West

NBER Working Paper No. 14959

May 2009

JEL No. I20,J24

\begin{abstract}
$\underline{\text { ABSTRACT }}$
Why aren't there more women in science? Female college students are currently 37 percent less likely than males to obtain a bachelor's degree in science, technology, engineering, and math (STEM), and comprise only 25 percent of the STEM workforce. This paper begins to shed light on this issue by exploiting a unique dataset of college students who have been randomly assigned to professors over a wide variety of mandatory standardized courses. We focus on the role of professor gender. Our results suggest that while professor gender has little impact on male students, it has a powerful effect on female students' performance in math and science classes, their likelihood of taking future math and science courses, and their likelihood of graduating with a STEM degree. The estimates are largest for female students with very strong math skills, who are arguably the students who are most suited to careers in science. Indeed, the gender gap in course grades and STEM majors is eradicated when high performing female students' introductory math and science classes are taught by female professors. In contrast, the gender of humanities professors has only minimal impact on student outcomes. We believe that these results are indicative of important environmental influences at work.
\end{abstract}

Scott E. Carrell

Department of Economics University of California, Davis

One Shields Avenue

Davis, CA 95616

and NBER

secarrell@ucdavis.edu

Marianne E. Page

Department of Economics

University of California, Davis

Davis, CA 95616-8578

and NBER

mepage@ucdavis.edu
James E. West

Department of Economics and Geosciences

U.S. Air Force Acdemy

2354 Fairchild Dr. \#6K100

USAF Academy, CO 80840

Jim.West@usafa.edu 
"The inferior sex has got a new exterior. We got doctors, lawyers, politicians too..."

(Annie Lennox, Sisters are doing it for Themselves)

\section{Introduction}

Why aren't there more women in science? During the past forty years, women have infiltrated many prestigious careers that were formerly dominated by men, and today the number of graduate degrees in medicine, business and law are almost equally divided across the sexes. In contrast, female college students are currently 37 percent less likely than males to obtain science and engineering BA's, ${ }^{1}$ and comprise only 25 percent of the science, technology, engineering and math (STEM) workforce. ${ }^{2}$ What is the source of this discrepancy and why does it continue to exist when women have successfully infiltrated so many other corners of the labor market? This question has spurred hundreds of academic studies, widely publicized conferences, and government reports, but the answers are still not well understood. As summarized in Xie and Shauman (2003), Women in Science

"Scholars have examined a variety of questions about women's participation in, exclusion from, and contributions to the fields of science and engineering. Despite the significant breadth and depth of this research, much of it suffers from conceptual and methodological limitations that restrict the significance and usefulness of its findings. As a consequence, we have only limited knowledge of the processes that produce the gender differences in science participation and attainment."

The exact manner in which cognitive and behavioral differences intertwine with social forces to produce differences in career outcomes is a subject of spirited debate. What we do know is that through $12^{\text {th }}$ grade, the gender gap in math and science achievement tests is very small, and that it has been declining over the past 20 years. ${ }^{3}$ The small differences that do exist are not predictive of men's higher likelihood of choosing a STEM career or major in college (Xie and Shauman 2003). Conditional on ability, the gender gap in the probability of completing a STEM degree is between 50 and 70 percent (Weinberger 1998, Weinberger 2001). Nor are the nearly non-existent differences

\footnotetext{
${ }^{1}$ National Bureau of Economic Research (2006)

${ }^{2}$ National Science Foundation (2006)

${ }^{3}$ Feingold (1988) Friedman (1989) Goldin, Katz, and Kuziemko (2006) Hyde (1981) Hyde, Fennema, and Lamon (1990) Leahey and Guo (2001) Linn and Hyde (1989) National Science Foundation (1904) Nowell and Hedges (1998) and Xie and Shauman (2003).
} 
in college preparatory math and science courses predictive of gender differences in college major (Xie and Shauman 2003). Since aptitude and preparedness of the two sexes seem roughly equal upon entering college, an important key to understanding the broader question of why men and women's representation in STEM careers is so different is understanding what happens to them during college.

This paper begins to shed light on this issue by exploiting a unique dataset of college students who have been randomly assigned to professors over a wide variety of mandatory standardized courses. We focus on the role of professor gender. Why might professor gender affect female students' propensity to persist in STEM? Role model effects are frequently cited as potentially important factors affecting educational outcomes (Stake and Granger 1978, Kahle and Matyas 1987, Jacobs 1996, DiPrete and Buchmann 2006). Other factors might include gender differences in the academic expectations of teachers, differences in teaching styles, or differences in the extent to which teachers provide advice and encouragement.

Randomized student placement, together with mandatory math and science courses at the particular school we study, allow us to investigate how professor gender influences student outcomes free of self-selection problems that plague existing research. At most universities students have a large degree of freedom in choosing both their courses and their professors, even in their first year, making it difficult to identify professors' causal impact. Students at our institution are required to take specific math and science courses in both their first year and in subsequent years, so it is possible for us to examine the long-term effects of professor gender on female students' success in STEM without worrying about attrition bias. To our knowledge, we are the only study that is able to address either the self-selection or attrition problems inherent in existing research.

It is important to point out that if professor gender impacts female students, then these influences occur at a critical juncture in the life-cycle. Decisions about choosing a STEM major are likely to have a substantial effect on future labor market opportunities. Furthermore, Xie and Shauman (2003) show that most women with a STEM bachelor's degree had initially planned on majoring in a non-STEM field. This suggests that the path towards a career in science is not primarily determined by the influence of social forces prior to college entry.

Our results suggest that while professor gender has only limited impact on male students, it has a powerful effect on female students' performance in math and science classes, their likelihood of taking future math and science courses, and their likelihood of graduating with a STEM degree. The estimates are robust to the inclusion of controls for students' initial ability, and they are substantively largest for students with high SAT math scores. Indeed, among these students, the 
gender gap in course grades and college major is eradicated when female students are assigned to introductory math and science professors who are female. The fact that professor gender effects are largest among women with strong math skills and a predisposition towards math and science is important because this group of women is, arguably, most suited to science and engineering careers. If we want to reduce the gender gap, these are precisely the women whom policies should target.

We also attempt to distinguish the role of professor gender itself from the role of other (unobservable) professor characteristics that are correlated with gender. We do this by estimating each professor's average "value-added" separately for male and female students and then looking at the value-added distributions. We find that some male professors are very effective at teaching female students - even more effective than they are at teaching male students. We also find the reverse - that some female professors are more effective at teaching male students. This suggests that the gender differences we observe are more likely to be driven by the manner in which the course is taught, than by the presence of female role models. Among the highest ability female students, however, the gender of introductory math and science professors continues to exert a positive influence on the choice of a STEM major, even after controlling for professors' value-added.

The remainder of the paper unfolds as follows: Section 2 briefly describes the literature on this important topic. Section 3 describes our dataset, and Section 4 discusses the statistical methods we will employ. In Sections 5 and 6 we present our main results and estimates based on alternative specifications. Section 7 discusses mechanisms. Section 8 concludes.

\section{Background}

There are many reasons that social scientists should care about understanding womens' underrepresentation in STEM careers. First, gender differences in entry into STEM careers explain a substantial portion of the gender pay differential among college graduates (Eide 1994, Brown and Corcoran 1997, Weinberger 1998, Weinberger 1999, Weinberger 2001, Weinberger 2006). Sociologists also argue that STEM is one of the most prestigious segments of the labor force (Hodge, Siegel, and Rossi 1964) and that compared to men, women's relatively low rates of participation in STEM careers contributes to their relatively lower social status (Jacobs 1996, Reskin 1984, Reskin, Hartmann, National Research Council Committee on Womens Employment and Related Social Issues, on Behavioral, Sciences, and Education 1986). Another concern is that the low representation of women in STEM careers leads to lower aggregate productivity than could be achieved if many of the women who choose non-STEM careers would have been qualified scientists and engineers 
(Xie and Shauman 2003, Weinberger 1998). Finally, Margolis and Fisher (2002) maintain that the direction of future technology development will depend on the interests and life experiences of STEM professionals. Taken together, these arguments suggest that the gender composition of the STEM workforce may affect both the level and types of production that takes place in the United States.

Most social scientists agree that gender differences in the labor market are likely attributable to a myriad of individual, familial, and social factors. Economists typically focus on the potential effects of discrimination and on differences in preferences (Black and Strahan 2001, Blau and Kahn 2000, Goldin and Rouse 2000, Altonji and Blank 1999, Blakemore and Low 1984, Polachek 1978) but a rich psychological literature suggests that equally skilled men and women may exhibit important differences that affect their labor market decisions. Beyer (1997) and Beyer and Bowden (1997), for example, find that there are gender differences in individuals' self perceptions of ability. Further research suggests that these perceptions are linked to individuals' expectations, aspirations, and preferences for taking on difficult tasks. ${ }^{4}$ Women tend to have lower expectations about their future performance than men (Beyer 1997, Elliot and Harackiewicz 1994), and they are more risk averse (e.g. Eckel and Grossman (2008)). If STEM classes or careers are considered to be particularly challenging then these gender differences may lead men and women to perform differently or make different choices about which college majors and/or careers to pursue even when they have comparable skills. Recent surveys of college students suggest that, indeed, women differentially avoid these fields because they either lack interest, believe that they will be unwelcome, or have concerns about the difficulty associated with relevant coursework (Weinberger 2006).

At the same time, evidence suggests that the gender gap in outcomes that arises from these psychological differences is mutable. For example, a growing body of experimental work shows that the phenomenon of "stereotype threat," can have substantive effects on individuals' test performance (Steele 1997, Spencer, Steele, and Quinn 1999), and that simply telling women that a math test does not show gender differences leads to improved test scores. Stereotype threat effects are observed even among women with high levels of proficiency and confidence (Weinberger 1998, Steele and Aronson 1995, Steele 1997, Spencer, Steele, and Quinn 1999, Aronson, Lustina, Good, Keough, Steele, and Brown 1999). Similarly, experimental research by Niederle and Yestrumskas (2008) finds that men take on challenging tasks 50 percent more often than comparably performing women, but that changes in institutional design that provide more flexible choices eliminates the gender gap among high performers. Numerous researchers have suggested that relatively few college women

\footnotetext{
${ }^{4}$ See Boggiano, Main, and Katz (1988), Cutrona, Cole, Colangelo, Assouline, and Russell (1994), Elliott and Dweck (1988) and Harackiewicz and Elliot (1993).
} 
choose STEM majors because they face social pressures to conform to gender norms. ${ }^{5}$ If these claims are true, then they provide further evidence that women's career choices are mutable.

There are numerous ways in which students' experiences in the classroom might lead to gender differences in orientation towards science and math. Teachers may have different academic expectations of boys and girls; they may employ different teaching styles, or provide different levels of attention, advice, and encouragement. The presence of female role models teaching STEM could also be influential. Thus, there is ample reason to believe that female college students' interest and ability in pursuing the initial steps towards a STEM career (e.g. doing well in math and science courses, choosing a STEM major) might be influenced by their learning environment.

Many studies have investigated the effects of teacher gender at the elementary and secondary school level ${ }^{6}$ but only a handful have considered the post-secondary level(Canes and Rosen 1995, Neumark and Gardecki 1998, Rothstein 1995, Bettinger and Long 2005, Hoffmann and Oreopoulos 2007). Most of these studies do not focus on STEM per se, and all of them face self-selection problems because the traditional university path enables students to choose their schools, courses, and/or professors. This has made it impossible for previous researchers to cleanly identify the estimated relationship between professor gender and student outcomes.

The data used in this paper are unique because the institution under study has a mandatory course of study in the first year, and employs class random assignment. Thus, neither the set of courses, nor the professor's gender is under the student's control. A further advantage of our dataset is that course grades are not determined by an individual student's professor. Instead, all faculty members teaching the same course use an identical syllabus and give the same exams during a common testing period. ${ }^{7}$ As a result, we can circumvent the selection and attrition problems inherent in previous studies, and provide the cleanest evidence to-date.

\footnotetext{
${ }^{5}$ See Arnold (1995), Badgett and Folbre (2003), Betz (1997), Betz and Hackett (1981), Betz and Hackett (1983), Eccles (1987), Hyde (1997), Hall and Sandler (1982), Hanson (1996), Lapan, Shaughnessy, and Boggs (1996), Leslie, McClure, and Oaxaca (1998), Lunneborg (1982), Seymour and Hewitt (2000), Tobias (1993), Tobias and Lin (1991) and Ware and Lee (1988).

${ }^{6}$ See Nixon and Robinson (1999), Ehrenberg, Goldhaber, and Brewer (1995), Dee (2005), Dee (2007), Holmlund and Sund (2007), Carrington, Tymms, and Merrell (2005), Carrington, Tymms, and Merrell (2008), Lahelma (2000) and Lavy and Schlosser (2007)

${ }^{7}$ While the students in Hoffman and Oreopoulos's dataset are not randomly assigned and do not take mandatory STEM courses, their dataset has one similarity to ours, which is that course grades are determined by a general exam that is given to all students enrolled in the course, regardless of which professor they have taken the course from.
} 


\section{Data}

Our data come from the United States Air Force Academy (USAFA). The Air Force Academy is a fully accredited undergraduate institution of higher education with an approximate annual enrollment of 4,500 students. All students attending the USAFA receive 100 percent scholarship to cover their tuition, room, and board. Additionally, each student receives a monthly stipend of $\$ 845$ to cover books, uniforms, computer, and other living expenses. All students are required to graduate within four years ${ }^{8}$ and typically serve a minimum five-year commitment as a commissioned officer in the United States Air Force following graduation.

Despite the military setting, in many ways the USAFA is comparable to other selective postsecondary institutions in the United States. Similar to most selective universities and liberal arts colleges, USAFA faculty have earned their graduate degrees from a broad sample of high quality programs in their respective fields. Approximately 40 percent of classroom instructors have terminal degrees, as one might find at a university where introductory coursework is taught by graduate student teaching assistants. On the other hand, the number of students per section in any given course rarely exceeds 25 , and student interaction with faculty members in and outside of the classroom is encouraged. In this respect, students' learning experiences at USAFA more closely resemble those of students who attend small liberal arts colleges. There are approximately 32 academic majors offered at USAFA across the humanities, social sciences, basic sciences, and engineering.

Students at USAFA are high achievers, with average math and verbal SAT scores at the $88^{\text {th }}$ and $85^{\text {th }}$ percentiles of the nationwide SAT distribution. ${ }^{9}$ Students are drawn from each Congressional district in the US by a highly competitive process, insuring geographic diversity. Fourteen-percent of applicants were admitted to USAFA in 2007. ${ }^{10}$ Approximately 17 percent of the students are female, five percent are black, seven percent are Hispanic and six percent are Asian. Seven percent of students at USAFA have a parent who graduated from a service academy and 17 percent have a parent who previously served in the military.

Table 1 presents statistics for USAFA and a set of comparison schools. We show the $25^{\text {th }}$ and $75^{\text {th }}$ percentiles of each school's verbal and SAT math scores, undergraduate enrollment, acceptance

\footnotetext{
${ }^{8}$ Special exceptions are given for religious missions, medical "set-backs", and other instances beyond the control of the individual.

${ }^{9}$ See http://professionals.collegeboard.com/profdownload/sat_percentile_ranks_2008.pdf for a SAT score distributions.

${ }^{10}$ See the National Center for Education Statistics: http://nces.ed.gov/globallocator/
} 
rates, and percent female for selected universities. SAT scores at USAFA are comparable to the SAT scores of students at top ranked public universities such as UCLA and UNC Chapel Hill, but, unlike these schools, only nineteen percent of USAFA students are female. This characteristic makes USAFA most comparable to selective universities that have strong traditions in science and technology, such as the Georgia Institute of Technology, or Renssaleur Polytechnical Institute. Our results are thus most salient for women who enter college with strong math skills, are already interested in science, and who are comfortable in a predominantly male environment. This group is not representative of all female college students, but it is a group that is highly salient . One could argue that students with strong math skills and an interest in science are precisely the types of students whom efforts to reduce the gender gap in STEM careers should target. Put differently, we think that our estimates speak most directly to the issue of women's persistence in STEM, rather the question of what causes women to enter STEM majors.

\subsection{The Dataset}

Our dataset includes 9, 481 students who comprise the USAFA graduating classes of 2000 through 2008. Data for each student's high school (pre-treatment) characteristics and their achievement while at the USAFA were provided by USAFA Institutional Research and Assessment and were stripped of individual identifiers by the USAFA Institutional Review Board. Student-level pretreatment data includes whether students were recruited as athletes, whether they attended a military preparatory school, and measures of their academic, athletic and leadership aptitude. Academic aptitude is measured through SAT verbal and SAT math scores and an academic composite computed by the USAFA admissions office, which is a weighted average of an individual's high school GPA, class rank, and the quality of the high school attended. The measure of pretreatment athletic aptitude is a score on a fitness test required by all applicants prior to entrance. ${ }^{11}$ The measure of pre-treatment leadership aptitude is a leadership composite computed by the USAFA admissions office, which is a weighted average of high school and community activities (e.g., student council offices, Eagle Scout, captain of sports team).

Table 2 provides summary statistics and Figure 1 plots the distribution of pre-treatment academic variables by gender. As in nationally representative samples, the upper tail of the math score distribution is somewhat thicker for male than it is for female students. Since our estimation strat-

\footnotetext{
${ }^{11}$ Barron, Ewing, and Waddell (2000) found a positive correlation between athletic participation and educational attainment and Carrell, Fullerton, and West (2008) found a positive correlation between fitness scores and academic achievement.
} 
egy is based on random assignment and includes pre-treatment characteristics as controls, small differences in the distribution will not contaminate the analysis.

Our academic performance measures consist of final grades in core courses for each individual student by course and section-semester-year. Students at USAFA are required to take a core set of approximately 30 courses in mathematics, basic sciences, social sciences, humanities, and engineering, but we focus only on mandatory introductory and follow-on courses in mathematics, physics, chemistry, engineering, history, and English. ${ }^{12}$ A distinct advantage of our dataset is that all students are required to take a follow-on related curriculum. Grades are determined on an A, $\mathrm{A}-, \mathrm{B}+, \mathrm{B}$ - . C - , D, F scale where an A is worth 4 grade points, an A- is 3.7 grade points, a B+ is 3.3 grade points, etc. The sample grade point average in core science courses is 2.72 among females and 2.85 among males. The grade point average in core humanities courses is 2.81 among females and 2.73 among males. We standardize these course grades to have a mean of zero and a variance of one.

We also examine students' decisions to enroll in optional follow-on math and science classes, whether they graduate with a bachelor's degree, and their choice of academic major. In our sample, female students are less likely than males to take higher level elective math courses (34 percent of females vs. 50 percent of males) and less likely to major in STEM (24 vs. 40 percent ${ }^{13}$ ), but are more likely to graduate ( 84 vs. 81 percent).

Individual professor-level data were obtained from USAFA historical archives and the USAFA Center for Education Excellence and were matched to the student achievement data for each course taught, by section-semester-year. ${ }^{14}$ We have information on each professor's academic rank, gender, education level (M.A. or Ph.D.), and years of teaching experience at USAFA. During the period we study, there were 251 different faculty members who taught introductory mathematics, chemistry, or physics courses. Nineteen-percent (47 of 251) of these faculty were female and taught 23-percent (289 of 1,244) of the introductory math and science course-sections. 112 different faculty members taught humanities courses, of which 21-percent (24) were female.

\footnotetext{
${ }^{12}$ Course descriptions for Math 130, 141, 142; Physics 110, 221; Chemistry 141, 142; History 101, 202; English 111,211 ; and the required engineering courses (aeronautical, astronautical, electrical, mechanical, civil, and thermo dynamics) can be found at: http://www.usafa.edu/df/dfr/curriculum/CHB.pdf

${ }^{13}$ Figures exclude the biological sciences, which require less mathematics and have historically higher rates of female participation. When including biological sciences the gender difference is smaller (40 vs. 45 percent).

${ }^{14}$ Due to the sensitivity of the data we were only able to obtain the professor observable data for the mathematics, chemistry, physics, English, and history departments. Due to the large number of faculty in these departments, a set of demographic characteristics (e.g., female assistant professor, PhD with 3 years of experience) does not uniquely identify an individual faculty member.
} 


\subsection{Student Assignment to Courses and Professors}

Prior to the beginning of the freshman year, students take placement exams in mathematics, chemistry, and select foreign languages, and the scores on these exams are used to place students into the appropriate beginning core courses (i.e., remedial math, Calculus I, Calculus II, etc.). Conditional on course placement, the USAFA Registrar randomly assigns students to core course sections. ${ }^{15}$ Thus, throughout their four years of study, students have no ability to choose their required core course professors. Since faculty members teaching the same course use an identical syllabus and give the same exams during a common testing period, grades in core courses are a consistent measure of relative achievement across all students. ${ }^{16}$ These institutional characteristics assure there is no self-selection of students into (or out of) courses or towards certain professors.

Table 2 indicates that the types of students assigned to female faculty are nearly indistinguishable from those assigned to male faculty. In math and science courses, the average class size for female faculty is 19.2 compared to 18.9 for males. In addition, male and female professors have a similar numbers of female students per section, and similar average scores on SAT verbal, SAT math, academic composite, and algebra/trigonometry tests.

To formally test whether course assignment is random with respect to student and faculty gender, we have regressed student gender on faculty gender, by course type. The results of this analysis are shown in specifications 1 and 2 of Table 3, where we see that the correlation between student and faculty gender is always small and statistically insignificant. In Specifications 3 through 5 we examine whether there are any differences in the types of female students who are assigned to female professors by regressing student attributes on an indicator variable for whether the student was assigned a female professor. Our estimates indicate that there is no sizeable or systematic correlation between professor gender and students' SAT and academic composite scores. For example, female students who are assigned to female math and science professors have slightly lower SAT math and verbal scores but slightly higher academic composite scores. The differences are of trivial magnitude, and most are not significantly different from zero. Specification 7, which combines the SAT and academic composite into one measure also produces an estimate of the relationship that is small, positive, and statistically insignificant. Carrell and West (2008) also show that student assignment to core courses at USAFA is random with respect to peer characteristics and faculty academic rank, experience, and terminal degree status.

\footnotetext{
${ }^{15}$ The one exception is introductory chemistry, where the 92 lowest ability freshman students each year are ability grouped into four separate sections and are taught by the most experienced professors.

${ }^{16}$ The one exception is that in some core courses at USAFA, 5 to 10 -percent of the overall course grade is earned by professor/section specific quizzes and/or class participation.
} 


\section{Statistical Methods}

We begin by estimating the following linear regression model:

$$
Y_{i c j s t}=\phi_{1}+\beta_{1} \text { Female }_{i}+\beta_{2} \text { Female }_{j}+\beta_{3} \text { Female }_{i} \text { Female }_{j}+\phi_{2} X_{i c s t}+\phi_{3} P_{j}+\gamma_{c t}+\epsilon_{i c j s t}
$$

where $Y_{i c j s t}$ is the outcome measure for student $i$ in course $c$ with professor $j$ in section $s$ in semester-year $t$. For academic performance outcomes, we normalize grades within each course and semester to have a mean of zero and variance of one. Female $i$ is an indicator for whether student $i$ is female and Female $_{j}$ is an indicator for whether professor $j$ is female. The $\beta$ coefficients are the primary coefficients of interest in our study. $\beta_{1}$ represents the difference in mean performance between female and male students. $\beta_{2}$ is the value added from having a female professor, and, $\beta_{3}$ indicates the extent to which having a female professor differentially affects female vs. male students. Because students are randomly assigned, estimates of the $\beta$ coefficients will be unbiased.

The vector $X_{i c s t}$ includes the following student characteristics: SAT math and SAT verbal test scores, academic and leadership composites, algebra/trigonometry placement test score, fitness score, race, whether the student was recruited as an athlete, and whether he/she attended a military preparatory school. $P_{j}$ is the academic rank of professor $j . \gamma_{c t}$ are course by semester-year fixed effects, which control for unobserved mean differences in academic achievement or grading standards across courses and time. The inclusion of these fixed effects ensures that the model identifies professor quality using only the within course by semester-year variation in student achievement. $\epsilon_{i c j s t}$ is the error term. Standard error estimates are clustered by professor.

We implement a slightly modified version of (1) to estimate the effect of professor gender in initial courses on performance in follow-on related courses:

$$
Y_{i c^{\prime} j s^{\prime} t^{\prime}}=\phi_{1}+\beta_{1} \text { Female }_{i}+\beta_{2} \frac{\sum_{j} \text { Female }_{j t}}{n_{i t}}+\beta_{3} \text { Female }_{i} \frac{\sum_{j} \text { Female }_{j t}}{n_{i t}}+\phi_{2} X_{i c s t}+\gamma_{c^{\prime} s^{\prime} t^{\prime}}+\epsilon_{i c^{\prime} j s^{\prime} t^{\prime}}
$$

where $Y_{i c^{\prime} j k s^{\prime} t^{\prime}}$ is performance in the follow-on course, $c^{\prime}$ in section $s^{\prime}$ and semester-year $t^{\prime}$, having

taken professor $j$ in the initial coursework. $\frac{\sum_{j} F_{e m a l e} j^{\prime}}{n_{i t^{\prime}}}$ is the proportion of introductory course faculty $j$ who were female for student $i$ at time $t^{\prime}$. To adjust for any possible professor, section, or year effects in the follow-on course, we include a section by course by semester-year fixed effect, $\gamma_{c^{\prime} s^{\prime} t^{\prime}}$. As in (1), we are primarily interested in the $\beta$ 's, which measure the average differences across male and female students, the effect of having more female professors in the introductory STEM courses, and the differential effect across male and female students of being assigned more female professors in introductory courses. 
To estimate the effect of professor gender on longer term outcomes, such as choosing to take higher level math or graduating with a technical degree, we estimate a variation of (2):

$$
D_{i t^{\prime}}=\phi_{1}+\beta_{1} \text { Female }_{i}+\beta_{2} \frac{\sum_{j} \text { Female }_{j t}}{n_{i t}}+\beta_{3} \text { Female }_{i} \frac{\sum_{j} \text { Female }_{j t}}{n_{i t}}+\phi_{2} X_{i t}+\epsilon_{i j t^{\prime}}
$$

Where $D_{i t^{\prime}}$ is a dummy variable that indicates whether student $i$ at time $t^{\prime}$ chose to take a higher level math course or chose a STEM major. As before, the $\beta$ coefficients are the coefficients of interest.

\section{Estimated Effects of Introductory Course Professor Gender in Science and Math Classes}

\subsection{Estimated Effects on Course Performance in the Professor's Own Course}

Figure 4 provides unconditional mean estimates by student and professor gender. The pattern of estimates shown in the figure are quantitatively and qualitatively similar to those produced by equation (1), which include all of the covariates discussed in the previous section and are shown in Table 4. The first two columns of Table 4 show the estimated effects for all students, while the remaining columns focus on students with increasingly strong math skills. We include detailed student-level control variables in Column 1; Column 2 replaces the control variables with individualstudent fixed effects.

For the full sample, our estimates on the female faculty dummy variable indicate that when male students are taught by female professors they end up with somewhat lower course grades than when they are taught by males. ${ }^{17}$ The coefficient on the female professor dummy is between -0.04 (Column 2) and -0.05 (Column 1), which suggests that female professors lower male students' course grades by about 4 to 5 percent of a standard deviation. The magnitude of the teacher gender effects is swamped, however, by the estimated coefficient on the female student dummy (Column 1, Row 2), which indicates that women, on average, score 16 percent of a standard deviation lower than men whose math skills were comparable upon entry into the USAFA. Given that we are controlling for initial skills, this is a dramatic discrepancy, which can only be documented because of the unique, randomized, nature of our study. In most university settings, the possibility of differential selection into courses would make it impossible to detect this phenomenon.

\footnotetext{
${ }^{17}$ The estimated effect is not statistically significant across all of the subsamples indicated in Columns 3-6 or across all of the robustness checks in Table 5
} 
The third row of Table 4 displays the estimated coefficient on the female student $\times$ female professor interaction. Focusing first on Column 1, we see that the estimate is of substantive magnitude (10 percent of a standard deviation) and positive, indicating that female students' performance in math and science courses improves substantially when the course is taught by a female professor. In fact, taken together with the estimates in rows 1 and 2, the estimated coefficient on the interaction term suggests that having a female professor reduces the gender gap in course grades by approximately two thirds. This finding reflects both the fact that male students do worse when they have a female professor, and that female students do significantly better. The absolute gain to women from having a female professor is 5 percent of a standard deviation $(-0.049+0.100)$.

The estimates shown in Column 1 are based on regressions that control for ability by including observables, and they provide information about the relative gains to men and women from having a male vs. female professor in first year math and science classes. The next column replaces the student control variables with an individual fixed effect. In this regression, the coefficient on the interaction term indicates how much better female students do when they have female professors, compared to their own performance in other mandatory first year math and science courses. When the estimated coefficients on the female professor dummy and interaction term are added together $(-.041+0.139)$ the resulting estimate indicates that, conditional on own ability, female students' performance improves by 10 percent of a standard deviation.

Columns 3 - 6 focus on women who entered college with very high math skills. Columns 3 and 4 show the regression estimates for students whose SAT math score was above 660 and Columns 5 and 6 show the same results for students who scored above 700 on the SAT math. These scores correspond to the median and $75^{\text {th }}$ percentile of the distribution at USAFA, and to the $90^{\text {th }}$ and $95^{\text {th }}$ percentiles of the national SAT Math distribution. Although not statistically different from one another, the pattern of the estimated coefficients provides suggestive evidence that the gender gap in course grades grows with math ability. Since we control for initial SAT math scores and math placement test scores in our regressions, this is unlikely to reflect men's higher likelihood of scoring at the very top of the distribution prior to college, rather, it suggests that either 1) there are gender differences in math/science ability that are not captured by the initial controls, or 2) something about the college experience has a particularly detrimental effect on the math and science performance of highly skilled women.

The most striking pattern in Table 4 is that as female students' initial math skills increase, the relative importance of professor gender also increases. In fact, at the top of the distribution (Column 5), having a female professor completely closes the gender gap $(-0.169+0.177)$. Notably, at higher skill levels, the evidence that professor gender matters to male students also weakens. 
We speculate that something about the classroom environment created by female math and science professors has a powerful effect on the performance of women with very strong math skills — with virtually no expense incurred by their comparable male peers. This is a particularly important result as men and women with strong math skills are arguably those whom we would most like to see entering STEM careers .

\subsection{Longer-term Effects of Professor Gender}

Our main finding is that female students perform substantively better in their math and science courses when they are taught by a woman. Since we are interested in understanding why the prevalence of women in science careers is lower than that of men, our next task is to examine whether these effects extend into longer-term outcomes; course performance itself is only interesting to the extent that it affects pathways into STEM careers. Table 5 provides the results from estimating the effect of professor gender (as measured by the proportion of introductory courses taught by female faculty) on longer-term outcomes. We look at four outcomes: whether the student withdraws from the USAFA, ${ }^{18}$ the student's performance in all required follow-on STEM coursework, ${ }^{19}$ whether the student chooses to take higher level math courses beyond those that are required for graduation with a non-STEM degree, and whether she graduates with a STEM degree. All four of these outcomes are correlated with future career choices. Columns 1-5 show that, conditional on entering math skills, women and men are equally likely to withdraw from the USAFA. However, female students perform significantly worse in follow-on STEM coursework, are less likely to take higher level math courses, and are less likely to graduate with a STEM degree compared to male students. It is also clear that gender differences in college major are much larger when we exclude biological sciences (Columns 4 vs. 3), which typically require less math, and have higher rates of female participation. $^{20}$

The estimated effect of professor gender on these long-term outcomes varies across the subsamples, with the biggest effects, by far, accruing to women with high entering math ability. Across the full sample, there is no statistically significant evidence that having a higher proportion of female professors affects a woman's likelihood of withdrawing, her performance in follow-on coursework, her probability of taking higher level math courses, or her probability of graduating

\footnotetext{
${ }^{18}$ The results we present in Table 5 show attrition after the second year; however, results are qualitatively similar for 1-year and 4-year attrition.

${ }^{19}$ See footnote 12 for a list of these courses

${ }^{20}$ We find qualitatively similar results when we also exclude environmental engineering, a field with a relatively higher rate of female participation.
} 
with a STEM major. However, as the sample narrows to include increasingly high skilled women (as approximated by their SAT math score), the estimated effects of professor gender become much larger and statistically significant. Among the top quartile of female students, and for each longterm outcome, higher proportions of female professors in introductory math and science courses are associated with reductions in the gender gap. In fact, the estimates suggest that increasing the fraction of female professors from 0 to 100 percent would completely eliminate the gender gap in math and science majors. For example, Column 5 of Panel $\mathrm{C}$ indicates that among the highest ability women, those whose introductory math and science professors are exclusively female are 26 percentage points more likely to major in STEM than those who are exclusively assigned to male faculty. For this high ability group, the male/female gap in the probability of completing a STEM major is 27-percent. At the same time, there is no evidence that having a female professor affects a female student's likelihood of dropping out, regardless of her ability level. This suggests that whatever it is about female professors that affects women in their first year math and science courses, it is not something that changes retention rates, but rather something that changes their preferences for math and science. This interpretation is consistent with Zafar (2009) who finds evidence at Northwestern University that the gender gap in academic majors is "due to differences in beliefs about enjoying coursework and differences in preferences."

\section{Robustness Checks}

\subsection{Alternative Specifications}

In Table 6, we examine our estimates' robustness to changes in model specification that either 1) exclude individual controls, or 2) increase flexibility. Differences between our main estimates and the results from the first exercise might indicate that our estimates are somehow driven by an unobserved correlation between student ability and professor assignment. The second exercise addresses the possibility that the relationship between entry level characteristics and student outcomes might vary with student gender. The estimates that are produced by these specifications are very similar to the estimates produced by (1).

We have also explored the possibility that our estimates are driven by a few female professors whose approach to teaching differs substantially from the rest of the faculty. In order to address this concern, we have run regressions that replace the female professor dummy in (1) with professor-level fixed effects, and looked at the distribution of the estimated fixed effects. We find that over $2 / 3$ of the female professor fixed effects are positive and statistically significant, which suggests that our 
estimated professor gender effects are pervasive, rather than driven by a handful of teachers.

\subsection{Estimated Effects of Professor Gender in English and History Classes}

Next, we consider the role of professor gender in humanities courses. Table 7 shows the estimated effects of professor gender when we estimate equation (1) for introductory English and history courses instead of math and science. The estimates are strikingly different. There is no observable gender gap in course performance, and there is no evidence that female students' course grades are improved when they have a female professor. As in Tables 4 and 5, we find weak evidence that both men and women have lower humanities grades when the course is taught by a female professor, but most of the coefficient estimates on the female professor dummy are barely significant at the 10 percent level. ${ }^{21}$ Specifications 3-6 carry forward our analyses for longer-term outcomes. We look at the effect of professor gender in initial humanities courses on later course selection and choice of major. All of the estimated female professor coefficients are small, and none are statistically significant. This indicates that the gender of professors in initial humanities courses has no effect on male students' longer-term choices. Similarly, most of the estimated coefficients on the interaction term are small, and only one is statistically different from zero, suggesting that female students' long run choices are also unrelated to the sex of the professor who teaches their humanities courses.

These results stand in direct contrast to our estimated professor effects in math and science, where it appears that female students with strong math skills are very strongly affected by the gender of their introductory course professors. The differences in results across science and the humanities also suggests that our math/science estimates are not likely driven by the general (military) culture of the institution we study.

\footnotetext{
${ }^{21}$ We have also estimated a fixed effects model analogous to the specification that is employed in Columns 2,4 , and 6 of Table 4. The results from this specification suggest that when male students are taught by women, their grades are about 20 percent of a standard deviation lower than their grades in similar classes not taught by women. Among female students, however, course performance seems to be unrelated to professor gender. Results are available upon request from the authors.
} 


\section{$7 \quad$ Mechanisms}

\subsection{Is it All About Professor Gender?}

Table 4 suggests that female students' initial math and science grades are substantively higher when they are taught by female professors. The estimated effects are particularly large among female students in the upper quartile of the SAT math distribution. In this section, we investigate whether gender differences in student performance are driven by professor gender per se, or whether they might be driven by some other professor characteristic that is correlated with professor gender. For example, male and female students may respond differently to different teaching styles and teaching styles may be correlated with, but not exclusive to, professor gender. In order to investigate this possibility, we implement a two-step process: first, we estimate a student-gender-specific random effect for each professor. ${ }^{22}$ This provides us with estimates of each professor's "value added" for both female and male students. Specifically, we estimate the following equation:

$$
Y_{i c j s t}=\phi_{1}+\beta_{1} \text { Female }_{i}+\phi_{2} X_{i c s t}+\left(1-\text { Female }_{i}\right) \xi_{m j}+\text { Female }_{i} \xi_{f j}+\gamma_{c t}+\epsilon_{i c j s t}
$$

where $\xi_{m j}$ is the random effect measuring the value added of professor $j$ for male students and $\xi_{f j}$ is the random effect measuring the value added of professor $j$ for female students. All other terms are defined as in equation (1).

Figure 5 shows the distribution of the gender-specific estimated random effects, $\hat{\xi}$. As expected, the distribution of the female-student-female-teacher effects (middle column) is to the right of the distribution of female-student-male-teacher effects. These results reconfirm our previous finding that, on average, female students perform better when their math and science courses are taught by female faculty, but also make clear that many male professors are very effective at teaching female students. In other words, student performance is correlated with professor gender, but not exclusively. This pattern suggests that the mechanism through which professor gender operates is more likely to be something like teaching style rather than "role modeling".

Our next step is to re-estimate the long-term outcome regressions, (equations (2) and (3)) while

\footnotetext{
${ }^{22}$ For recent work estimating teacher value-added models see Rivkin, Hanushek, and Kain (2005), Kane, Rockoff, and Staiger (2008), Kane and Staiger (2008), Hoffmann and Oreopoulos (2009), and Carrell and West (2008).
} 
including the average of the estimated random effects, $\hat{\xi}$, as explanatory variables.

$$
\begin{aligned}
Y_{i c^{\prime} j s^{\prime} t^{\prime}}= & \phi_{1}+\beta_{1} \text { Female }_{i}+\beta_{2} \text { Female }_{i} \frac{\sum_{j} \hat{\xi}_{f j}}{n_{i t}}+\beta_{3} \text { Female }_{i} \frac{\sum_{j} \hat{\xi}_{m j}}{n_{i t}}+\beta_{4} \text { Female }_{i} \frac{\sum_{j} \text { Female }_{j t}}{n_{i t}} \\
& +\beta_{5}\left(1-\text { Female }_{i}\right) \frac{\sum_{j} \hat{\xi}_{f j}}{n_{i t}}+\beta_{6}\left(1-\text { Female }_{i}\right) \frac{\sum_{j} \hat{\xi}_{m j}}{n_{i t}}+\beta_{7}\left(1-\text { Female }_{i}\right) \frac{\sum_{j} \text { Female }_{j t}}{n_{i t}} \\
& +\phi_{2} X_{i c s t}+\gamma_{c^{\prime} s^{\prime} t^{\prime}}+\epsilon_{i c^{\prime} j s^{\prime} t^{\prime}}
\end{aligned}
$$

This equation allows us to investigate whether students' long term outcomes are affected by professors who have high "male or female value-added," conditional on professor gender. In other words, we can separately estimate the impact of professor "quality" from the impact of professor gender itself. We present results for this analysis in Table 8. Column 1 shows that the male and female "value-added" variables are strong predictors of student performance in mandatory follow-on STEM courses even though we control for professor gender. Furthermore, the sign of the value-added estimates depend on the gender of the student. Among female students, the estimates suggest that a 1-standard deviation increase in initial course female-student professor value-added results in a $0.110(0.110=2.554 * 0.043)$ standard deviation increase in follow-on course grades. Conversely, female students appear to respond negatively to professors with high male-student professor valueadded. A 1-standard deviation increase in the initial course male-student professor value-added effect results in a $0.030(-0.030=-0.492 * 0.060)$ standard deviation decrease in follow-on course grades.

What these results tell us is that, on average, male and female students respond differently to introductory math and science instruction, regardless of the professor's gender. The estimates in Columns 4 and 7 indicate that the relationship between initial course value-added and follow-on course performance is just as strong among high ability students. In addition, when the value-added estimates are included, the magnitude of the estimated coefficient on the proportion female faculty variable is much smaller (for female students) than the estimated coefficients shown in Table 5. Thus, it appears that the influence of female professors on their female students' future math and science performance operates largely through environmental factors (rather than role models) that affect students' initial class performance. These factors are correlated with, but are not exclusive to, professor gender.

The remaining columns in Table 8 show how teacher value-added affects students' future decisions. Our main finding is that these measures strongly predict high ability students' (both male and female) probability of graduating with a STEM degree. Column 9, for example, indicates 
that a 1-standard deviation increase in female-student value-added increases the probability that a female student graduates with a STEM degree by 6.3 percentage points $(0.063=1.704 * 0.037)$. At the same time, including the teacher value-added variables reduces, but does not eliminate, the estimated importance of professor gender. Thus the gender of the introductory course professor continues to have a marginally significant effect on high ability female students' longer-run STEM trajectories.

\subsection{The Influence of Professor Gender in Follow-on Courses}

We have seen evidence that female students' paths into math and science careers are influenced by the sex of the professors who teach their initial math and science courses. Table 4 shows that at least part of the mechanism through which the influence of professor gender operates is through its effect on female students' initial course performance. Table 9, however, shows that it is only the gender of professors in introductory courses that matter. When we estimate the effect of professor gender in mandatory follow-on math and science courses on own course grades, whether the student takes

higher level math, and whether the student graduates with a degree in STEM, we find that none of the estimated interaction terms are statistically different from zero, most are small in magnitude, and a few are in the opposite direction from our earlier estimates. This suggests that classroom environment has its strongest influence early in the college career.

\section{Conclusion}

Why aren't there more women in science careers? If we want to know the answer to this question then we need to understand what happens to women in college. College is a critical juncture in the life-cycle, and in spite of the fact that men and women enter college with similar levels of math preparation, women have substantially lower probabilities of majoring in science or engineering than their male counterparts. This, in turn, closes the door to many careers in science and technology.

The goal of this paper has been to shed light on how women's paths towards science are affected by the college environment, focusing on the role of professor gender. Unlike previous research on this topic, we are blessed with experimental conditions that ensure our estimates are uncontaminated by self-selection and attrition problems. This is possible because the campus that we study randomly assigns students to professors over a wide variety of mandatory standardized courses. A further advantage of our data is that course grades are not determined by an individual student's professor. 
The unique nature of our data allows us to document a number of interesting patterns. First, we find that compared to men with the same entering math ability, female students perform substantially less well in their introductory math and science courses. This is a new fact that is only knowable because of the mandatory nature of introductory math and science courses at the USAFA. We document a gender gap in most other dimensions of STEM success, as well. Second, we find that the gender gap is mitigated considerably when female students have female professors. Conversely, professor gender seems to be irrelevant in the humanities. Third, we find that the effect of female professors on female students is largest among students with high math ability. In particular, we find that among students in the upper quartile of the SAT math distribution, being assigned to a female professor eliminates the gender gap in introductory course grades and science majors. This is and important finding because these are precisely the women whom we would like to keep in science. We also find that professor gender has minimal effects on male students' outcomes.

This research raises a number of interesting questions about why professor gender is important, particularly at the top of the ability distribution. Do female professors serve as role models? Do they teach in ways that female students find more accessible? Are they more encouraging of their female students? We have begun to investigate these questions by looking at the distribution of each professor's gender-specific, average value-added. We find that professor value-added is correlated with professor gender, but is not exclusive to it. This suggests that role model effects are unlikely to be the primary reason that professor gender matters. In future research, we hope to investigate whether there are observable characteristics of male and female teachers that can help explain this phenomenon. While this is not possible with our current data, it would provide invaluable information to policymakers who seek to improve women's representation in science.

\section{References}

Altonji, J. B., and R. Blank (1999): "Race and Gender in the Labor Market," in Handbook of Labor Economics, ed. by O. Ashenfelter, and D. Card, vol. 3c, pp. 3144-3259. Elsevier.

Arnold, K. (1995): Lives of Promise: What Becomes of High School Valedictorians: A Fourteenyear Study of Achievement and Life Choices. Jossey-Bass, San Francisco, CA.

Aronson, J., M. J. Lustina, C. Good, K. Keough, C. M. Steele, and J. Brown (1999): "When White Men Can’t Do Math: Necessary and Sufficient Factors in Stereotype Threat," Journal of Experimental Social Psychology, 35(1), 2946. 
Badgett, M. V. L., And N. Folbre (2003): "Job Gendering: Occupational Choice and the Marriage Market," Industrial Relations: A Journal of Economy and Society, 42(2), 270-298.

Barron, J. M., B. T. Ewing, and G. R. Waddell (2000): "The Effects of High School Participation on Education and Labor Market Outcomes," The Review of Economics and Statistics, 82(3), 409-421.

Bettinger, E., And B. T. Long (2005): "Do Faculty Serve as Role Models? The Impact of Instructor Gender on Female Students," American Economic Review, 95(2), 152-157.

Betz, N. (1997): "What Stops Women and Minorities from Choosing and Completing Majors in Science and Engineering?," in Minorities and Girls in School: Effects on Achievement and Performance, ed. by D. Johnson, and D. H. Johnson, pp. 105-140. Sage Publications.

Betz, N. E., and G. Hackett (1981): "The Relationship of Career-Related Self-Efficacy Expectations to Perceived Career Options in College Women and Men," Journal of Counseling Psychology, 28(5), 399-410.

(1983): "The Relationship of Mathematics Self-Efficacy Expectations to the Selection of Science-Based College Majors," Journal of Vocational Behavior, 23(3), 329-345.

Beyer, S. (1997): "Gender Differences in the Accuracy of Self-Evaluations of Performance," Personality and Social Psychology Bulletin, 23(1), 960-970.

Beyer, S., And E. M. Bowden (1997): "Gender Differences in Self-Perceptions: Convergent Evidence from Three Measures of Accuracy and Bias," Personality and Social Psychology Bulletin, $23(1), 157-172$.

Black, S. L., and P. E. Strahan (2001): "The Division of Spoils: Rent-sharing and discrimination in a regulated industry," American Economic Review, 91(4), 814-831.

Blakemore, A. E., And S. A. Low (1984): "Sex Differences in Occupational Selection: The Case of College Majors," The Review of Economics and Statistics, 66(1), 157-163.

Blau, F. D., And L. M. Kahn (2000): "Gender Differences in Pay," The Journal of Economic Perspectives, 14(4), 75-99.

Boggiano, A. K., D. S. Main, and P. A. Katz (1988): "Children's Preference for Challenge: The Role of Perceived Competence and Control," Journal of Personality and Social Psychology, $54(1), 134-141$. 
Brown, C., And M. Corcoran (1997): "Sex-Based Differences in School Content and the MaleFemale Wage Gap," Journal of Labor Economics, 15(3), 431-465.

Canes, B., And H. Rosen (1995): "Following in Her Footsteps? Faculty Gender Composition and Womens Choices of College Majors," Industrial and Labor Relations Review, 48(3), 486-504.

Carrell, S. E., R. L. Fullerton, and J. E. West (2008): "Does Your Cohort Matter? Estimating Peer Effects in College Achievement," Working Paper 14032, National Bureau of Economic Research.

Carrell, S. E., And J. E. West (2008): "Does Professor Quality Matter? Evidence from Random Assignment of Students to Professors," Working Paper 14081, National Bureau of Economic Research.

Carrington, B., P. Tymms, and C. Merrell (2005): "Forget Gender: Whether a Teacher is Male or Female Doesn't Matter," in Teacher, vol. 11. Australian Council for Educational Research.

(2008): "Role Models, School Improvement and the 'Gender Gap': Do Men Bring Out the Best in Boys and Women the Best in Girls?," British Educational Research Journal, 34(3), $315-327$.

Cutrona, C. E., V. Cole, N. Colangelo, S. G. Assouline, and D. W. Russell (1994): "Perceived Parental Social Support and Academic Achievement: An Attachment Theory Perspective," Journal of Personality and Social Psychology, 66(2), 369-378.

DeE, T. S. (2005): "A Teacher Like Me: Does Race, Ethnicity, or Gender Matter?," American Economic Review, 95(2), 158-165.

- (2007): "Teachers and the Gender Gaps in Student Achievement," J. Human Resources, $42(3), 528-554$.

DiPrete, T. A., and C. Buchmann (2006): "Gender-Specific Trends in the Value of Education and the Emerging Gender Gap in College Completion," Demography, 43(1), 1-24.

Eccles, J. S. (1987): “Gender Roles and Women's Achievement-Related Decisions," Psychology of Women Quarterly, 11(2), 135-172.

Eckel, C. C., And P. J. Grossman (2008): "The Difference in the Economic Decisions of Men and Women: Experimental Evidence," in Handbook of Experimental Economics Results, ed. by C. Plott, and V. Smith, vol. 1. Elsevier. 
Ehrenberg, R. G., D. D. Goldhaber, and D. J. Brewer (1995): “Do Teachers' Race, Gender, and Ethnicity Matter? Evidence from the National Educational Longitudinal Study of 1988," Industrial and Labor Relations Review, 48(3), 547-561.

EIDE, E. (1994): "College Major Choice and Changes in the Gender Wage Gap," Contemporary Economic Policy, 12(2), 55-64.

Elliot, A. J., and J. M. Harackiewicz (1994): "Goal Setting, Achievement Orientation, and Intrinsic Motivation: A Mediational Analysis," Journal of Personality and Social Psychology, 66(5), 968-980.

Elliott, E. S., And C. S. Dweck (1988): "Goals: An approach to motivation and achievement," Journal of Personality and Social Psychology, 54(1), 5-12.

Feingold, A. (1988): "Does Cognitive Gender Differences are Disappearing," American Psychologist, 43(2), 95-103.

Friedman, L. (1989): "Mathematics and the Gender Gap: A Meta-Analysis of Recent Studies on Sex Differences in Mathematical Tasks," Review of Educational Research, 59(2), 185-213.

Goldin, C., L. Katz, and I. Kuziemko (2006): "The Homecoming of American College Women: The Reversal of the College Gender Gap," Journal of Economic Perspectives, 20(4), 133-156.

Goldin, C., And C. Rouse (2000): "Orchestrating Impartiality: The Impact of "Blind Auditions on Female Musicians," American Economic Review, 90(4), 715-742.

Hall, R. M., And B. R. Sandler (1982): "The Classroom Climate: A Chilly One for Women?," Report 1982-02-00, Association of American Colleges.

Hanson, S. L. (1996): "Lost Talent: Women in the Sciences," Report, Temple University Press.

Harackiewicz, J. M., And A. J. Elliot (1993): "Achievement Goals and Intrinsic Motivation," Journal of Personality and Social Psychology, 65(5), 904-915.

Hodge, R. W., P. M. Siegel, and P. H. Rossi (1964): "Occupational Prestige in the United States, 1925-63," American Journal of Sociology, 70(3), 286.

Hoffmann, F., and P. Oreopoulos (2007): "A Professor Like Me: The Influence of Instructor Gender on College Achievement," Working Paper 13182, National Bureau of Economic Research. (2009): "Professor Qualities and Student Achievement," Review of Economics and Statistics, 91(1), 83-92. 
Holmlund, H., And K. Sund (2007): "Is the Gender Gap in School Performance Affected by the Sex of the Teacher," Labour Economics, 15(1), 37-53.

Hyde, J. S. (1981): "How Large are Cognitive Gender Differences? A Meta-Analysis using ! $w^{2}$ and d," American Psychologist, 36(8), 892-901.

Hyde, J. S. (1997): "Gender Differences in Math Performance: Not Big, Not Biological," in Women, Men, and Gender: Ongoing Debates, ed. by M. R. Walsh, pp. 283-287. Yale University Press.

Hyde, J. S., E. Fennema, and S. J. Lamon (1990): "Gender Differences in Mathematics Performance: A Meta-Analysis," Psychological Bulletin, 107(2), 139-155.

Jacobs, J. A. (1996): "Gender Inequality and Higher Education," Annual Review of Sociology, $22(1), 153-185$.

Kahle, J. B., And M. L. Matyas (1987): "Equitable Science and Mathematics Education: A Discrepancy Model," in Women: Their Underrepresentation and Career Differentials in Science and Engineering, ed. by L. S. Dix, vol. 3c. National Academy Press.

Kane, T. J., J. E. Rockoff, and D. O. Staiger (2008): "What does certification tell us about teacher effectiveness? Evidence from New York City," Economics of Education Review, 27(6), 615631.

Kane, T. J., And D. O. Staiger (2008): "Estimating Teacher Impacts on Student Achievement: An Experimental Evaluation," Working Paper 14607, National Bureau of Economic Research.

Lahelma, E. (2000): "Lack of Male Teachers: A Problem for Students or Teachers?," Pedagogy, Culture and Society, 8(2), 173-186.

Lapan, R. T., P. Shaughnessy, and K. Boggs (1996): "Efficacy Expectations and Vocational Interests as Mediators between Sex and Choice of Math/Science College Majors: A Longitudinal Study," Journal of Vocational Behavior, 49(3), 277291.

Lavy, V., And A. Schlosser (2007): "Does Being with More Girls in School Improve Students Human Capital Outcomes and Behavior? Evidence on Effects and Mechanisms," unpublished manuscript.

Leahey, E., And G. Guo (2001): "Gender Differences in Mathematical Trajectories," Social Forces, 80(2), 713-732. 
Leslie, L. L., G. T. McClure, and R. L. Oaxaca (1998): "Women and Minorities in Science and Engineering. A Life Sequence Analysis," Journal of Higher Education, 69(3), 239-276.

Linn, M. C., And J. S. Hyde (1989): "Gender, Mathematics, and Science," Educational Researcher, 18(8), 17-27.

Lunneborg, P. W. (1982): "Role Model Influences of Nontraditional Professional Women," Journal of Vocational Behavior, 20(3), 276-281.

Margolis, J., And A. Fisher (2002): Unlocking the Clubhouse: Women in Computing. The MIT Press, Cambridge, MA.

National Bureau of Economic Research (2006): "Diversifying the Science and Engineering Workforce: Women, Underrepresented Minorities, and Their Science and Engineering Careers," http://www.nber.org/sewp/events/2005.01.14/Agenda-1-14-05-WEB.htm.

National Science Foundation (1904): "Women, Minorities, and Persons with Disabilities in Science and Engineering: 1994," Discussion Paper NSF 94-333, National Science Foundation, Division of Science Resources Studies.

(2006): "Science and Engineering Degrees: 1966-2004," Discussion Paper NSF 07-307, National Science Foundation, Division of Science Resources Statistics.

Neumark, D., and R. Gardecki (1998): "Women Helping Women? Role Model and Mentoring Effects on Female Ph.D. Students in Economics," Journal of Human Resources, 33(1), 220-46.

Niederle, M., And A. H. Yestrumskas (2008): "Gender Differences in Seeking Challenges: The Role of Institutions," Working Paper 13922, National Bureau of Economic Research.

Nixon, L. A., And M. D. Robinson (1999): "The Educational Attainment of Young Women: Role Model Effects of Female High School Faculty," Demography, 36(2), 185-194.

Nowell, A., And L. V. Hedges (1998): "Trends in Gender Differences in Academic Achievement from 1960 to 1994: An Analysis of Differences in Mean, Variance, and Extreme Scores," Sex Roles: A Journal of Research, 39(1-2), 21-43.

PolacheK, S. W. (1978): "Sex differences in college major," Industrial and Labor Relations Review, 31(4), 498-508.

Reskin, B. F. (1984): Sex Segregation in the Workplace: Trends, Explanations, Remedies. National Academy Press. 
Reskin, B. F., H. I. Hartmann, National Research Council Committee on Womens Employment and Related Social Issues, N. R. C. C. on Behavioral, S. Sciences, and Educhtion (1986): Womens Work, Mens Work: Sex Segregation on the Job. National Academy Press.

Rivkin, S. G., E. A. Hanushek, and J. F. Kain (2005): "Teachers, Schools and Academic Achievement," Econometrica, 73(2), 417-58.

Rothstein, D. S. (1995): "Do Female Faculty Influence Female Students Educational and Labor Market Attainments?," Industrial and Labor Relations Review, 48(3), 515-30.

Seymour, E., And N. M. HewitT (2000): Talking About Leaving: Why Undergraduates Leave the Sciences. Westview Press, 2 edn.

Spencer, S. J., C. M. Steele, and D. M. Quinn (1999): "Stereotype Threat and Womens Math Performance," Journal of Experimental Social Psychology, 35(1), 4-28.

Stake, J. E., and C. R. Granger (1978): "Same-Sex and Opposite-Sex Teacher Model Influences on Science Career Commitment Among High School Students," Journal of Educational Psychology, 70(2), 180-186.

Steele, C. M. (1997): "A Threat in the Air: How Stereotypes Shape Intellectual Identity and Performance," American Psychologist, 52(6), 613-629.

Steele, C. M., and J. Aronson (1995): "Stereotype Threat and the Intellectual Test Performance of African Americans," Journal of Personality and Social Psychology, 69(5), 797-811.

Tobias, S. (1993): Overcoming Math Anxiety. W. W. Norton and Company, New York, NY.

Tobias, S., And H. Lin (1991): "They're Not Dumb, They're Different: Stalking the Second Tier," American Journal of Physics, 59(12), 1155-1157.

Ware, N. C., And V. E. Lee (1988): "Sex Differences in Choice of College Science Majors," American Educational Research Journal, 25(4), 593-614.

Weinberger, C. J. (1998): "Race and Gender Wage Gaps in the Market for Recent College Graduates," Industrial Relations, 37(1), 67-84.

(1999): "Mathematical College Majors and the Gender Gap in Wages," Industrial Relations, 38(3), 407-413. 
(2001): "Is Teaching More Girls More Math the Key to Higher Wages?," in Squaring Up: Policy Strategies to Raise Womens Incomes in the U.S., ed. by M. C. King. The University of Michigan Press.

— (2006): "Economists' Perspective on College Educated Women in the Information Technology Workforce," in Encyclopedia of Gender and Information Technology, ed. by E. M. Trauth. Idea Group Publishing.

Xie, Y., And K. A. Shauman (2003): Women in Science: Career Processes and Outcomes. Harvard University Press, Cambridge, MA.

ZAfar, B. (2009): "College Major Choice and the Gender Gap," Working Paper. 
Figure 1: Distribution of Academic Pre-treatment Measures by Gender
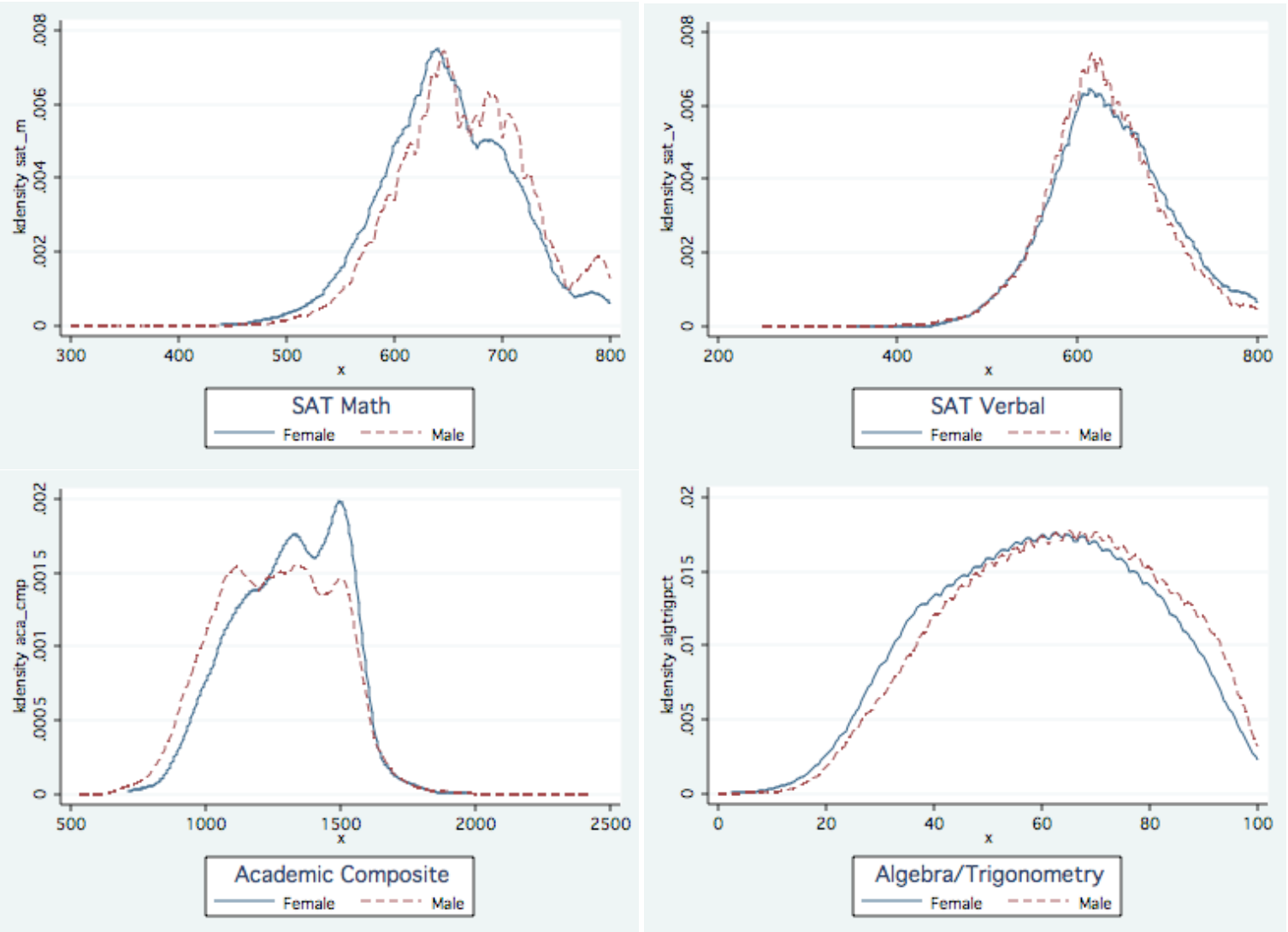
Figure 2: Math and Science Courses: Distribution of Female Student Pre-treatment Characteristics by Professor Gender
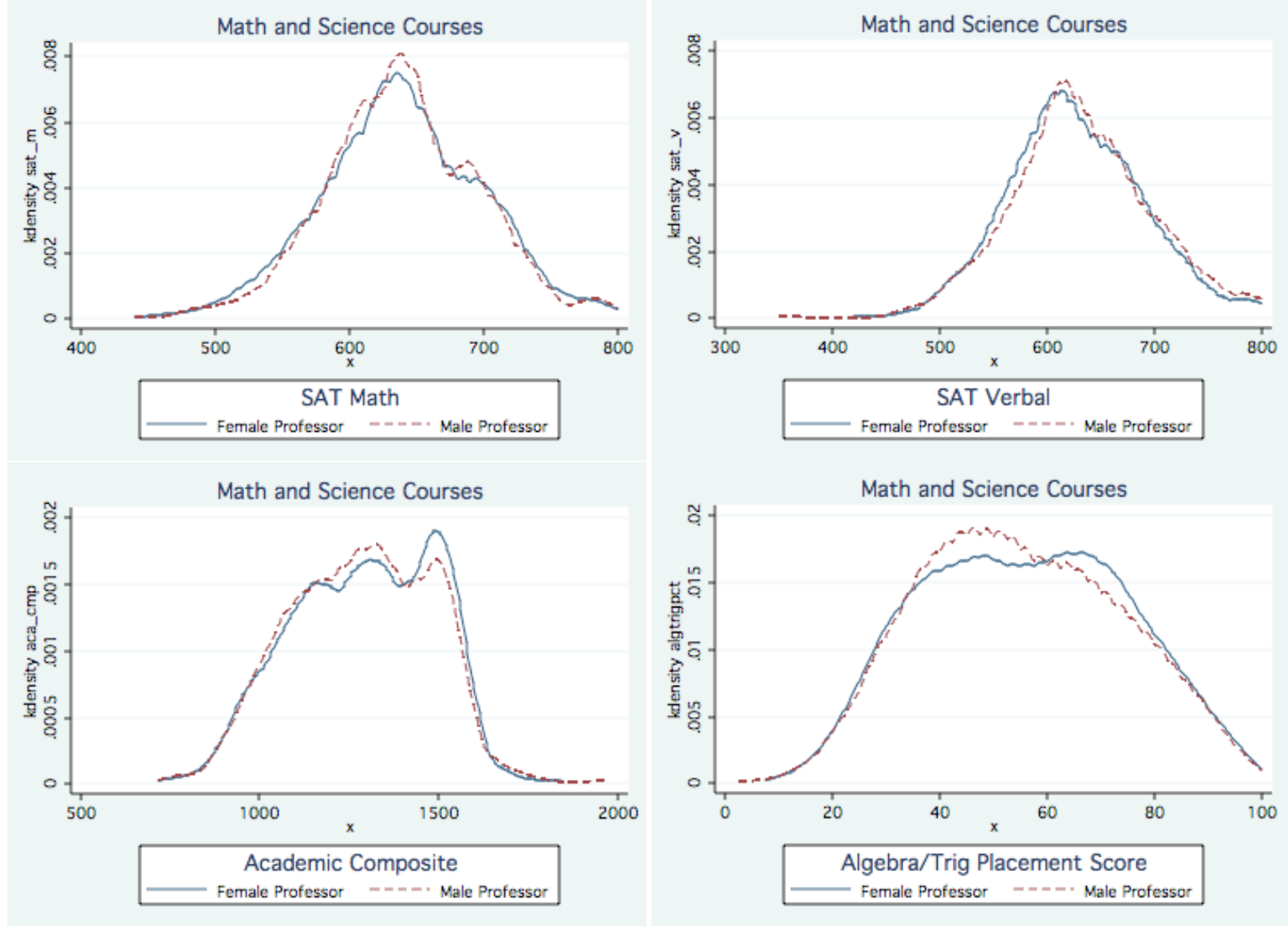
Figure 3: Humanities Courses: Distribution of Female Student Pre-treatment Characteristics by Professor Gender
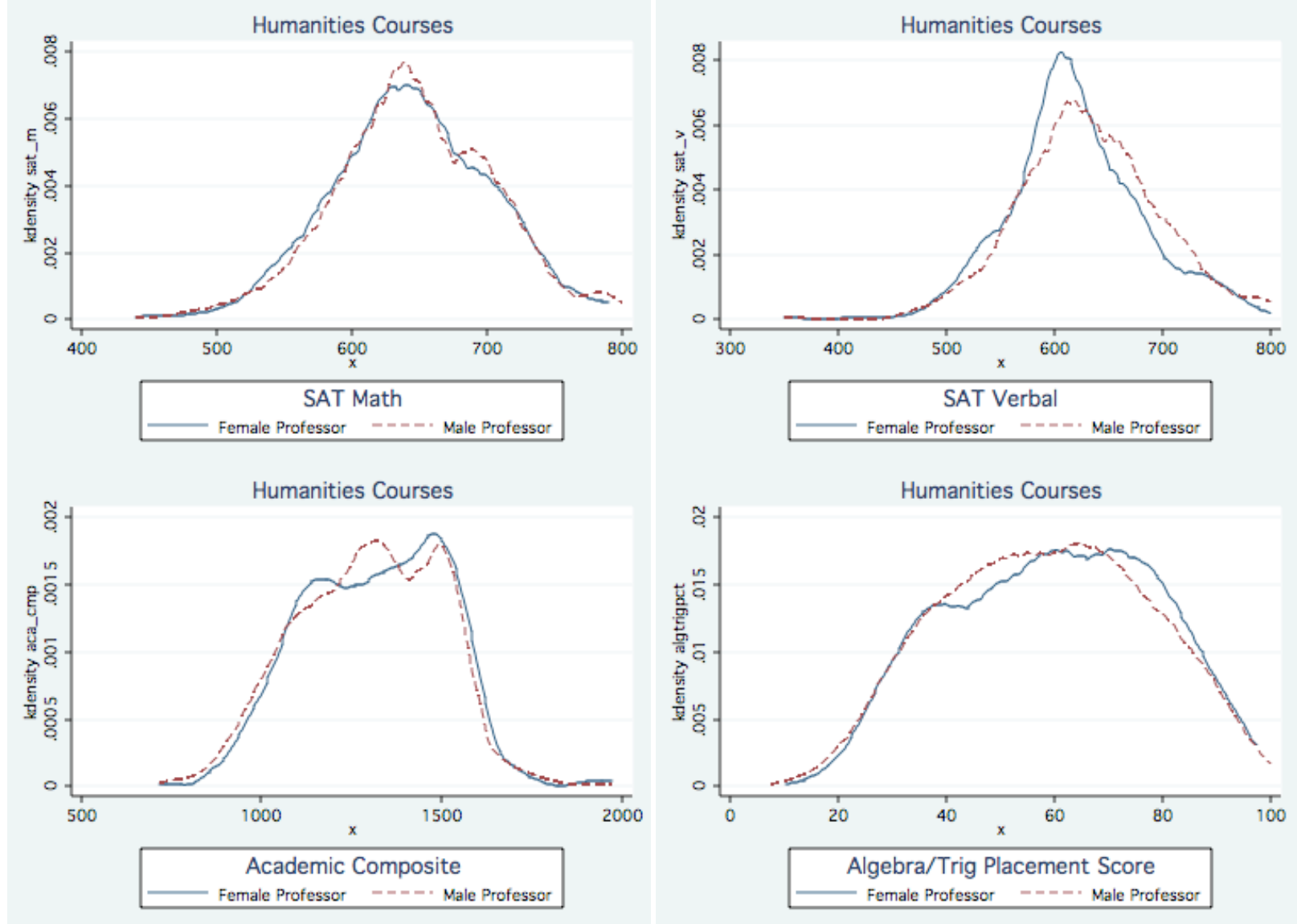
Figure 4: Unconditional Mean Performance by Student and Professor Gender
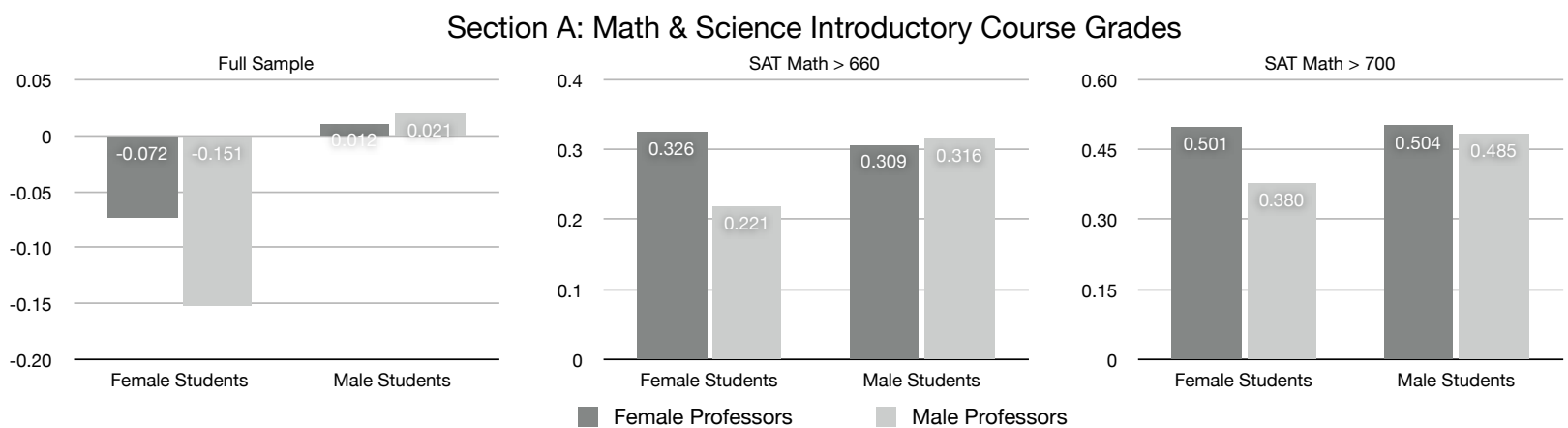

Section B: Math \& Science Follow-on Course Grades
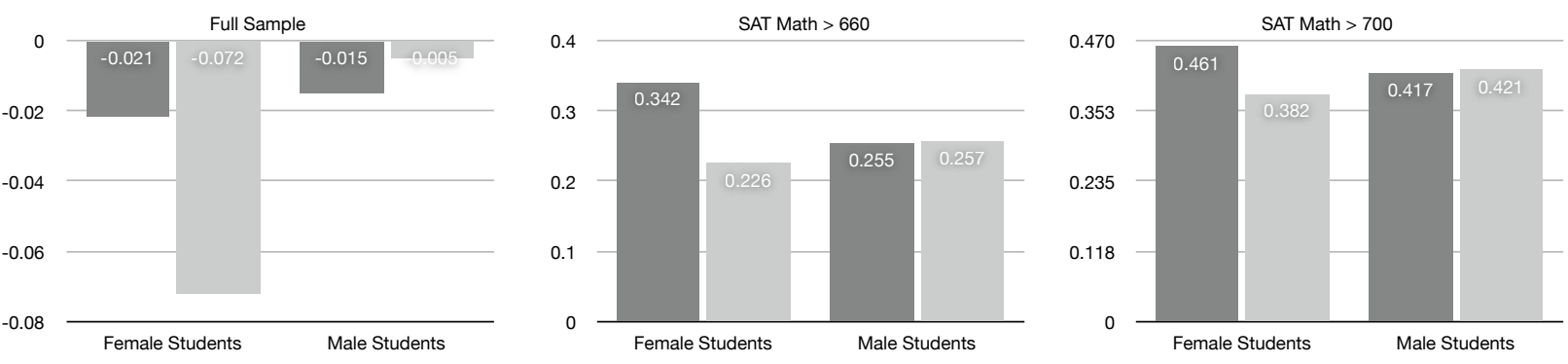

Female Professors Male Professors

Section C: Take Higher Level Math
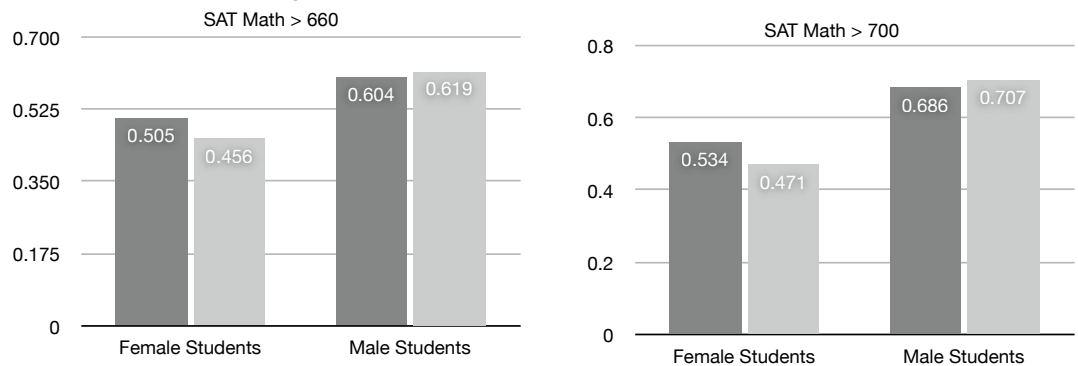

Female Professors Male Professors

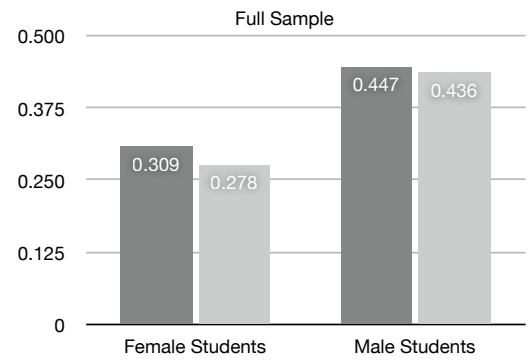

Section D: Graduate with a Math, Science, or Engineering Major
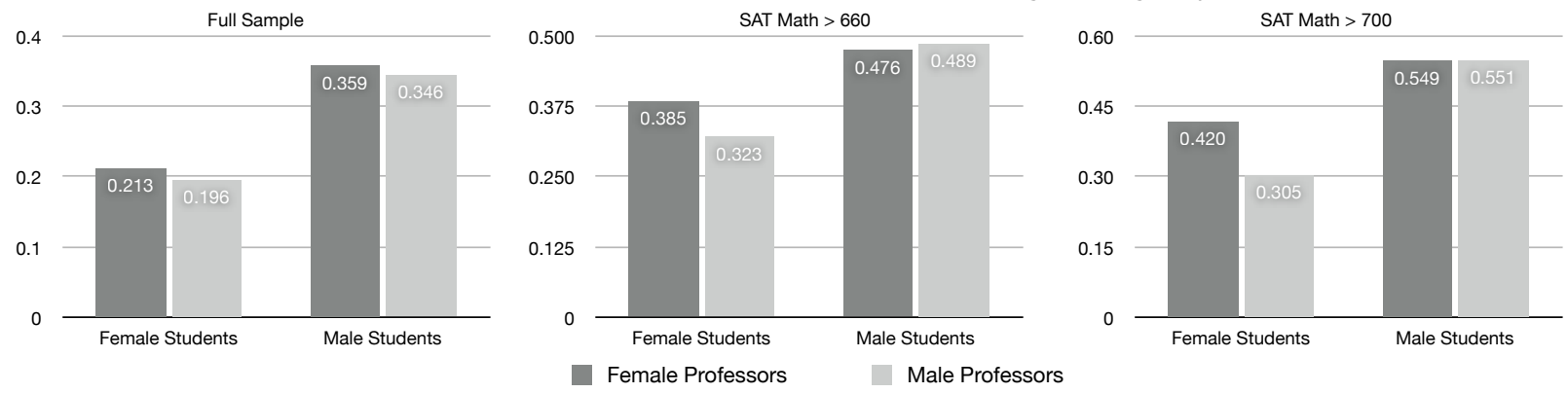
Figure 5: Distribution of Professor Value-Added by Student and Professor Gender
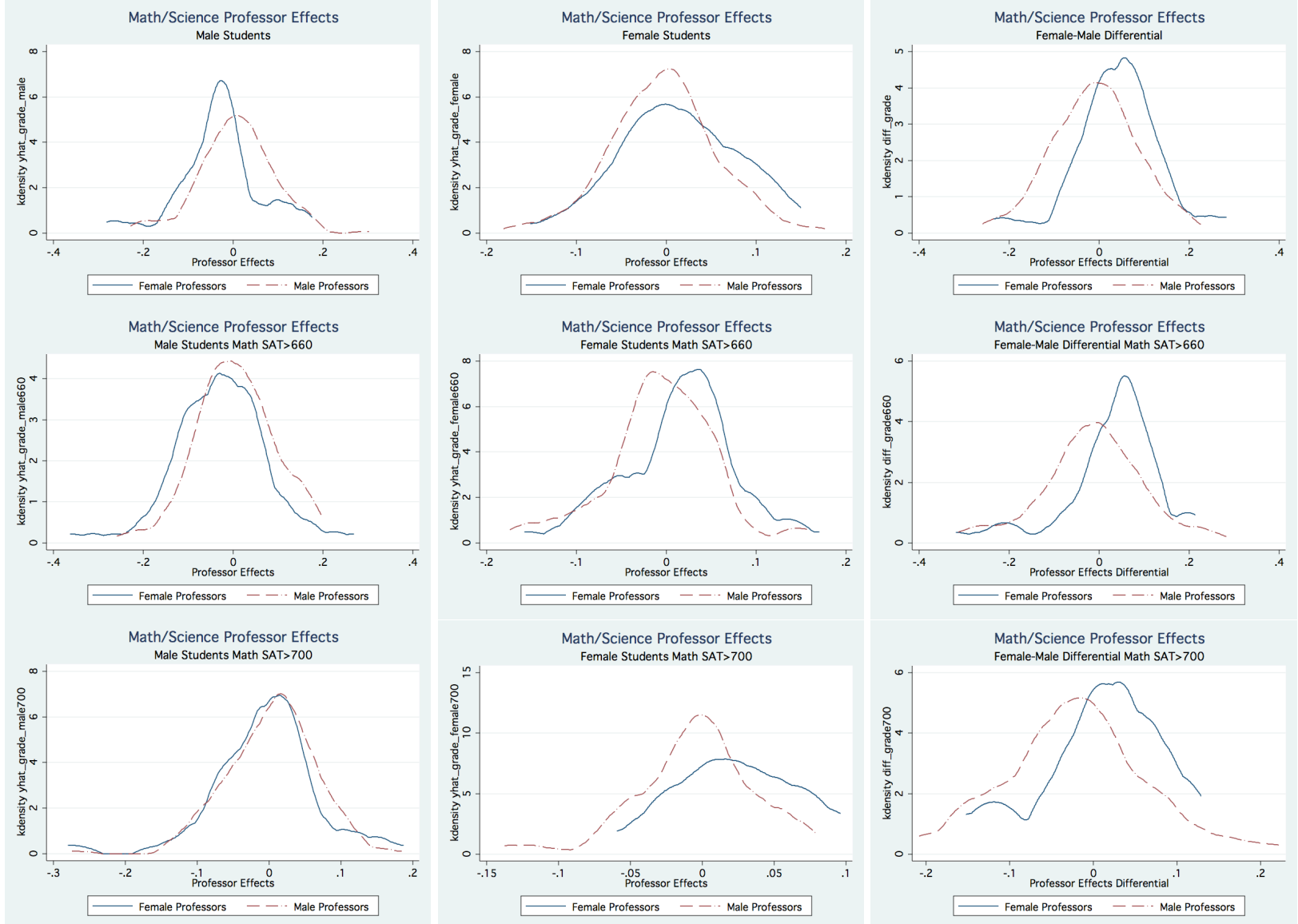
Table 1: Comparison Schools

\begin{tabular}{lrrrrrrr}
\hline & Percent & \multicolumn{2}{c}{ SAT Verbal } & SAT Math & 2007 & Percent \\
\hline & Female & \multirow{2}{*}{ 25th } & \multirow{2}{*}{ 75th } & 25th & 75th & $\begin{array}{c}\text { Undergraduate } \\
\text { Enrollment }\end{array}$ & Admitted \\
\hline \hline Kettering University & 14.9 & 510 & 630 & 600 & 690 & 2,178 & 23.0 \\
Air Force Academy & $\mathbf{1 8 . 6}$ & $\mathbf{5 9 0}$ & $\mathbf{6 7 0}$ & $\mathbf{6 2 0}$ & $\mathbf{7 0 0}$ & $\mathbf{4 , 4 6 1}$ & $\mathbf{1 4 . 0}$ \\
Rose-Hulman Institute of Technology & 20.6 & 560 & 680 & 630 & 710 & 1,936 & 69.7 \\
Rennselaer Polytechnic Institute & 26.6 & 600 & 690 & 650 & 730 & 5,146 & 49.4 \\
Georgia Tech & 28.6 & 590 & 690 & 650 & 730 & 17,936 & 28.0 \\
California Institute of Technology & 30.6 & 700 & 780 & 770 & 800 & 913 & 16.9 \\
Virginia Tech & 41.6 & 530 & 630 & 570 & 670 & 23,041 & 67.1 \\
Case-Western Reserve University & 42.3 & 580 & 690 & 620 & 720 & 4,207 & 74.7 \\
UCLA & 44.7 & 570 & 680 & 610 & 720 & 25,928 & 25.8 \\
University of Illinois at Urbana Champaign & 46.9 & 550 & 670 & 640 & 740 & 31,472 & 71.0 \\
University of Michigan & 50.3 & 590 & 690 & 630 & 730 & 25,555 & 50.3 \\
UC San Diego & 52.6 & 540 & 660 & 600 & 700 & 22,048 & 45.6 \\
University of Virginia & 55.8 & 590 & 700 & 610 & 720 & 15,078 & 35.2 \\
UNC Chapel Hill & 58.7 & 590 & 690 & 610 & 700 & 17,628 & 34.1 \\
\hline Nin
\end{tabular}

Notes: Data originally from National Center for Education Statistics (2007 - 2008) 
Table 2: Summary Statistics

\begin{tabular}{|c|c|c|c|c|c|c|}
\hline & \multicolumn{3}{|c|}{ Female Students } & \multicolumn{3}{|c|}{ Male Students } \\
\hline Student-Level Variables & Observations & Mean & Std. Dev. & Observations & Mean & Std. Dev. \\
\hline Total Course Hours & $1,1,595$ & 25.00 & 6.45 & 7,886 & 24.96 & 6.59 \\
\hline $\begin{array}{l}\text { Math and Science Core Course Grades } \\
\text { (normalized course by semester) }\end{array}$ & 7,825 & -0.10 & 0.99 & 37,949 & 0.02 & 1.00 \\
\hline $\begin{array}{l}\text { English and History Core Course Grades } \\
\text { (normalized by course by semester) }\end{array}$ & 5,680 & 0.08 & 0.99 & 28,882 & -0.02 & 1.00 \\
\hline Withdraw in First Year & 1,595 & 0.05 & 0.23 & 7,886 & 0.06 & 0.24 \\
\hline Withdraw in First or Second Year & 1,595 & 0.13 & 0.34 & 7,886 & 0.15 & 0.36 \\
\hline Take Higher Level Math Elective & 1,595 & 0.34 & 0.47 & 7,886 & 0.50 & 0.50 \\
\hline Take Higher Level Humanities Elective & 1,595 & 0.26 & 0.44 & 7,886 & 0.23 & 0.42 \\
\hline Graduate & 1,595 & 0.84 & 0.36 & 7,886 & 0.81 & 0.39 \\
\hline Graduate with a Math, Science or Engineering Degree & 1,595 & 0.40 & 0.49 & 7,886 & 0.45 & 0.50 \\
\hline $\begin{array}{l}\text { Graduate with a Math, Science or Engineering Degree } \\
\text { (excludes biological sciences) }\end{array}$ & 1,595 & 0.24 & 0.43 & 7,886 & 0.40 & 0.49 \\
\hline Graduate with a Humanities Degree & 1,595 & 0.10 & 0.30 & 7,886 & 0.07 & 0.26 \\
\hline Proportion Female Professors (Introductory Math \& Science) & 1,576 & 0.23 & 0.28 & 7,757 & 0.23 & 0.28 \\
\hline Proportion Female Professors (Introductory Humanities) & 1,502 & 0.16 & 0.28 & 7,514 & 0.15 & 0.27 \\
\hline SAT Verbal & 1,595 & 636.51 & 66.67 & 7,886 & 629.22 & 64.39 \\
\hline SAT Math & 1,595 & 648.45 & 59.71 & 7,886 & 664.90 & 61.14 \\
\hline Academic Composite & 1,595 & 1306.96 & 196.97 & 7,885 & 1258.61 & 216.70 \\
\hline Algebra/Trigonometry Placement Score & 1,586 & 59.34 & 19.24 & 7,832 & 62.36 & 19.39 \\
\hline Leadership Composite & 1,594 & 17.67 & 1.92 & 7,878 & 17.25 & 1.83 \\
\hline Fitness Score & 1,593 & 4.70 & 0.92 & 7,884 & 4.88 & 0.95 \\
\hline Black & 1,595 & 0.07 & 0.26 & 7,886 & 0.05 & 0.22 \\
\hline Hispanic & 1,595 & 0.08 & 0.27 & 7,886 & 0.07 & 0.25 \\
\hline Asian & 1,595 & 0.07 & 0.26 & 7,886 & 0.04 & 0.20 \\
\hline Recruited Athlete & 1,595 & 0.32 & 0.47 & 7,886 & 0.26 & 0.44 \\
\hline Attended Preparatory School & 1,595 & 0.16 & 0.37 & 7,886 & 0.21 & 0.41 \\
\hline Math, Physics, and Chemistry Courses & Femal & e Professo & & Male & Professors & \\
\hline Professor-Level Variables & Observations & Mean & Std. Dev. & Observations & Mean & Std. Dev. \\
\hline Number of Sections Per Instructor & 47 & 6.15 & 4.51 & 204 & 4.68 & 3.37 \\
\hline Instructor is a Lecturer & 47 & 0.57 & 0.50 & 202 & 0.42 & 0.49 \\
\hline Instructor is an Assistant Professor & 47 & 0.30 & 0.46 & 202 & 0.37 & 0.48 \\
\hline Instructor is an Associate Professor & 47 & 0.09 & 0.28 & 202 & 0.09 & 0.29 \\
\hline Instructor is a Full Professor & 47 & 0.04 & 0.20 & 202 & 0.12 & 0.33 \\
\hline Instructor has a Terminal Degree & 47 & 0.28 & 0.45 & 202 & 0.42 & 0.50 \\
\hline Instructor's Teaching Experience & 47 & 3.17 & 3.16 & 202 & 4.77 & 6.03 \\
\hline Class-Level Variables & Observations & Mean & Std. Dev. & Observations & Mean & Std. Dev. \\
\hline Class Size & 289 & 19.17 & 3.10 & 955 & 18.94 & 3.92 \\
\hline Average Number of Female Students & 289 & 3.32 & 1.83 & 955 & 3.26 & 1.98 \\
\hline Average Class SAT Verbal & 289 & 625.03 & 22.48 & 955 & 625.38 & 26.86 \\
\hline Average Class SAT Math & 289 & 653.07 & 28.71 & 955 & 650.62 & 32.38 \\
\hline Average Class Academic Composite & 289 & 12.47 & 0.88 & 955 & 12.38 & 1.02 \\
\hline Average Class Algebra/Trig Score & 289 & 57.90 & 11.96 & 955 & 56.42 & 12.09 \\
\hline English and History Courses & Femal & e Professo & & Male & Professors & \\
\hline Professor-Level Variables & Observations & Mean & Std. Dev. & Observations & Mean & Std. Dev. \\
\hline Number of Sections Per Instructor & 24 & 6.96 & 5.74 & 88 & 8.95 & 7.43 \\
\hline Instructor is a Lecturer & 24 & 0.54 & 0.51 & 88 & 0.52 & 0.50 \\
\hline Instructor is an Assistant Professor & 24 & 0.42 & 0.50 & 88 & 0.33 & 0.47 \\
\hline Instructor is an Associate Professor & 24 & 0.00 & 0.00 & 88 & 0.07 & 0.25 \\
\hline Instructor is a Full Professor & 24 & 0.04 & 0.20 & 88 & 0.08 & 0.27 \\
\hline Instructor has a Terminal Degree & 24 & 0.17 & 0.38 & 88 & 0.32 & 0.47 \\
\hline Instructor's Teaching Experience & 24 & 3.35 & 3.31 & 88 & 4.42 & 5.04 \\
\hline Class-Level Variables & Observations & Mean & Std. Dev. & Observations & Mean & Std. Dev. \\
\hline Class Size & 167 & 15.17 & 4.83 & 788 & 16.15 & 3.87 \\
\hline Average Number of Female Students & 167 & 2.58 & 1.82 & 788 & 2.59 & 1.73 \\
\hline Average Class SAT Verbal & 167 & 622.88 & 28.28 & 788 & 627.68 & 27.91 \\
\hline Average Class SAT Math & 167 & 658.89 & 28.39 & 788 & 662.11 & 27.20 \\
\hline Average Class Academic Composite & 167 & 12.75 & 0.94 & 788 & 12.64 & 0.96 \\
\hline Average Class Algebra/Trig Score & 167 & 61.67 & 8.54 & 788 & 61.90 & 8.03 \\
\hline
\end{tabular}


Table 3: Randomness Check Regressions of Faculty Gender on Student Characteristics Sample All Students Female Students

\begin{tabular}{|c|c|c|c|c|c|c|c|}
\hline Dependent Variable & $\begin{array}{l}\text { Female } \\
\text { Student }\end{array}$ & $\begin{array}{l}\text { Female } \\
\text { Student }\end{array}$ & $\begin{array}{l}\text { SAT } \\
\text { Math }\end{array}$ & $\begin{array}{c}\text { SAT } \\
\text { Verbal }\end{array}$ & $\begin{array}{l}\text { Academic } \\
\text { Composite }\end{array}$ & $\begin{array}{c}\text { Total }= \\
\text { SAT }+ \text { AC }\end{array}$ & $\begin{array}{c}\text { Algebra/Trig } \\
\text { Placement }\end{array}$ \\
\hline Specification & 1 & 2 & 3 & 4 & 5 & 6 & 7 \\
\hline Math and Science Courses & $\begin{array}{c}0.006 \\
(0.006)\end{array}$ & $\begin{array}{c}0.005 \\
(0.006)\end{array}$ & $\begin{array}{l}-1.462 \\
(2.393)\end{array}$ & $\begin{array}{l}-4.688 * \\
(2.784)\end{array}$ & $\begin{array}{c}9.682 \\
(8.281)\end{array}$ & $\begin{array}{c}3.532 \\
(10.61)\end{array}$ & $\begin{array}{c}0.405 \\
(0.679)\end{array}$ \\
\hline Observations & 23,630 & 23,455 & 4,076 & 4,076 & 4,076 & 4,076 & 4,056 \\
\hline Humanities Courses & $\begin{array}{c}0.015 \\
(0.009)\end{array}$ & $\begin{array}{c}0.012 \\
(0.009)\end{array}$ & $\begin{array}{l}-0.679 \\
(3.484)\end{array}$ & $\begin{array}{c}-8.626 * * \\
(3.601)\end{array}$ & $\begin{array}{c}24.250 * * \\
(11.432)\end{array}$ & $\begin{array}{c}14.944 \\
(14.355)\end{array}$ & $\begin{array}{c}1.273 \\
(1.136)\end{array}$ \\
\hline Observations & 15,261 & 15,132 & 2,471 & 2,471 & 2,471 & 2,471 & 2,458 \\
\hline $\begin{array}{l}\text { Mean and Std Dev of } \\
\text { Dependent Variable }\end{array}$ & \multicolumn{2}{|c|}{$\begin{array}{c}0.168 \\
(0.374)\end{array}$} & $\begin{array}{l}642.3 \\
(58.4)\end{array}$ & $\begin{array}{l}630.5 \\
(65.4)\end{array}$ & $\begin{array}{l}1,292.9 \\
(197.2)\end{array}$ & $\begin{array}{l}2,565.6 \\
(243.6)\end{array}$ & $56.6 \quad(18.9)$ \\
\hline Individual Control Variables & No & Yes & No & No & No & No & No \\
\hline
\end{tabular}

Notes: Each cell represents results for separate regression where the independent variable is an indicator variable for female faculty and the dependent variable is listed above. All specifications include a course by semester by year fixed effect. Individual control variables in Specification 2 include SAT verbal, SAT math, academic composite, algebra/trig placement score, leadership composite, fitness score, and indicator variables for black, Hispanic, Asian, recruited athlete, and attended a preparatory school. Standard errors are clustered at the course by semester by section level. * Significant at the 0.10 level, ** Significant at the 0.05 level, *** Significant at the 0.01 level. 
Table 4: Math and Science Introductory Course Professor Gender Effects on Initial Course Perfor-

\begin{tabular}{|c|c|c|c|c|c|c|}
\hline \multirow{2}{*}{$\begin{array}{l}\text { Sample } \\
\text { Specification }\end{array}$} & \multicolumn{2}{|c|}{ All Students } & \multicolumn{2}{|c|}{$\begin{array}{c}\text { SAT Math }>660 \\
(\text { median })\end{array}$} & \multicolumn{2}{|c|}{$\begin{array}{c}\text { SAT Math }>700 \\
\text { (75th pctile) }\end{array}$} \\
\hline & 1 & 2 & 3 & 4 & 5 & 6 \\
\hline Female Professor & $\begin{array}{c}-0.049 * \\
(0.028)\end{array}$ & $\begin{array}{c}-0.041 * * \\
(0.021)\end{array}$ & $\begin{array}{l}-0.049 \\
(0.035)\end{array}$ & $\begin{array}{l}-0.015 \\
(0.026)\end{array}$ & $\begin{array}{l}-0.021 \\
(0.037)\end{array}$ & $\begin{array}{c}0.032 \\
(0.034)\end{array}$ \\
\hline Female Student & $\begin{array}{c}-0.156^{* * *} \\
(0.021)\end{array}$ & NA & $\begin{array}{c}-0.160 * * * \\
(0.032)\end{array}$ & NA & $\begin{array}{c}-0.169 * * * \\
(0.043)\end{array}$ & NA \\
\hline Female Student * Female Professor & $\begin{array}{l}0.100 * * \\
(0.045)\end{array}$ & $\begin{array}{c}0.139 * * \\
(0.034)\end{array}$ & $\begin{array}{l}0.125^{*} \\
(0.071) \\
\end{array}$ & $\begin{array}{c}0.079 \\
(0.058) \\
\end{array}$ & $\begin{array}{c}0.177 * * \\
(0.079)\end{array}$ & $\begin{array}{l}0.169 * * \\
(0.069)\end{array}$ \\
\hline Observations & 23,383 & 23,557 & 9,255 & 9,317 & 4,070 & 4,105 \\
\hline $\mathrm{R}^{2}$ & 0.2756 & 0.7586 & 0.2497 & 0.7685 & 0.2484 & 0.7746 \\
\hline Individual Fixed Effect & No & Yes & No & Yes & No & Yes \\
\hline Individual Controls & Yes & No & Yes & No & Yes & No \\
\hline Course by Semester Fixed Effects & Yes & Yes & Yes & Yes & Yes & Yes \\
\hline Graduation Class Fixed Effects & Yes & No & Yes & No & Yes & No \\
\hline Time of Day Dummies & Yes & Yes & Yes & Yes & Yes & Yes \\
\hline
\end{tabular}

Notes: * Significant at the 0.10 level, ** Significant at the 0.05 level, *** Significant at the 0.01 level. Robust standard errors in parentheses are clustered by instructor. All specifications control for the academic rank of the professor. Individual-level controls include: SAT verbal, SAT math, academic composite, leadership composite, fitness score, algebra/trig placement score and indicator variables for students who are black, Hispanic, Asian, female, recruited athlete, and attended a preparatory school. 
Table 5: Math and Science Introductory Course Professor Gender Effects on Longer Term Outcomes

\begin{tabular}{|c|c|c|c|c|c|}
\hline \multicolumn{6}{|l|}{ Panel A. All Students } \\
\hline Specification & 1 & 2 & 3 & 4 & 5 \\
\hline Outcome & $\begin{array}{l}\text { Withdraw in } \\
\text { First 2-Years }\end{array}$ & $\begin{array}{c}\text { Follow-on } \\
\text { STEM Course } \\
\text { Performance }\end{array}$ & $\begin{array}{l}\text { Take Higher } \\
\text { Level Math }\end{array}$ & \multicolumn{2}{|c|}{$\begin{array}{c}\text { Graduate with STEM } \\
\text { Degree }^{+}\end{array}$} \\
\hline $\begin{array}{l}\text { Proportion of Professors Female } \\
\text { (Introductory Courses) }\end{array}$ & $\begin{array}{c}0.013 \\
(0.014)\end{array}$ & $\begin{array}{l}-0.046^{*} \\
(0.027)\end{array}$ & $\begin{array}{l}-0.006 \\
(0.018)\end{array}$ & $\begin{array}{c}0.011 \\
(0.019)\end{array}$ & $\begin{array}{c}0.003 \\
(0.018)\end{array}$ \\
\hline Female Student & $\begin{array}{c}0.001 \\
(0.013)\end{array}$ & $\begin{array}{l}-0.058 * * * \\
(0.023)\end{array}$ & $\begin{array}{l}-0.136 * * * \\
(0.016)\end{array}$ & $\begin{array}{c}-0.034 * * * \\
(0.017)\end{array}$ & $\begin{array}{c}-0.129 * * * \\
(0.016)\end{array}$ \\
\hline $\begin{array}{l}\text { Female Student * Proportion of } \\
\text { Professors Female }\end{array}$ & $\begin{array}{l}-0.054 \\
(0.035)\end{array}$ & $\begin{array}{c}0.055 \\
(0.061) \\
\end{array}$ & $\begin{array}{c}0.064 \\
(0.043) \\
\end{array}$ & $\begin{array}{c}0.041 \\
(0.045) \\
\end{array}$ & $\begin{array}{c}0.020 \\
(0.043) \\
\end{array}$ \\
\hline Observations & 9,258 & 61,125 & 9,258 & 9,258 & 9,258 \\
\hline $\mathrm{R}^{2}$ & 0.0394 & 0.3179 & 0.2420 & 0.1716 & 0.1825 \\
\hline \multicolumn{6}{|l|}{ Panel B. SAT Math > 660 (median) } \\
\hline Specification & 1 & 2 & 3 & 4 & 5 \\
\hline $\begin{array}{l}\text { Proportion of Professors Female } \\
\text { (Introductory Courses) }\end{array}$ & $\begin{array}{c}0.003 \\
(0.018)\end{array}$ & $\begin{array}{l}-0.070^{* *} \\
(0.033)\end{array}$ & $\begin{array}{l}-0.038 \\
(0.025)\end{array}$ & $\begin{array}{l}-0.004 \\
(0.026)\end{array}$ & $\begin{array}{l}-0.035 \\
(0.026)\end{array}$ \\
\hline Female Student & $\begin{array}{c}0.006 \\
(0.019)\end{array}$ & $\begin{array}{l}-0.075^{* *} \\
(0.033)\end{array}$ & $\begin{array}{l}-0.166^{* * *} \\
(0.026)\end{array}$ & $\begin{array}{c}-0.059^{* * *} \\
(0.027)\end{array}$ & $\begin{array}{c}-0.174 * * * \\
(0.027)\end{array}$ \\
\hline $\begin{array}{l}\text { Female Student * Proportion of } \\
\text { Professors Female }\end{array}$ & $\begin{array}{l}-0.077 \\
(0.048)\end{array}$ & $\begin{array}{r}0.185^{* *} \\
(0.078)\end{array}$ & $\begin{array}{c}0.127^{* *} \\
(0.065)\end{array}$ & $\begin{array}{c}0.161 * * \\
(0.069)\end{array}$ & $\begin{array}{c}0.143^{* *} \\
(0.070)\end{array}$ \\
\hline Observations & 4,255 & 27,826 & 4,255 & 4,255 & 4,255 \\
\hline $\mathrm{R}^{2}$ & 0.0251 & 0.3415 & 0.1458 & 0.1066 & 0.1141 \\
\hline \multicolumn{6}{|c|}{ Panel C. SAT Math > 700 (75th pctile) } \\
\hline Specification & 1 & 2 & 3 & 4 & 5 \\
\hline $\begin{array}{l}\text { Proportion of Professors Female } \\
\text { (Introductory Courses) }\end{array}$ & $\begin{array}{l}-0.011 \\
(0.025)\end{array}$ & $\begin{array}{l}-0.096^{* *} \\
(0.046)\end{array}$ & $\begin{array}{l}-0.034 \\
(0.033)\end{array}$ & $\begin{array}{l}0.026 \\
(0.036)\end{array}$ & $\begin{array}{l}0.009 \\
(0.036)\end{array}$ \\
\hline Female Student & $\begin{array}{c}0.030 \\
(0.028)\end{array}$ & $\begin{array}{l}-0.112 * * \\
(0.051)\end{array}$ & $\begin{array}{c}-0.239 * * * \\
(0.037)\end{array}$ & $\begin{array}{c}-0.079 * * * \\
(0.041)\end{array}$ & $\begin{array}{c}-0.269 * * * \\
(0.041)\end{array}$ \\
\hline $\begin{array}{l}\text { Female Student* Proportion of } \\
\text { Professors Female }\end{array}$ & $\begin{array}{l}-0.095 \\
(0.068)\end{array}$ & $\begin{array}{r}0.236^{* *} \\
(0.116) \\
\end{array}$ & $\begin{array}{l}0.204 * * \\
(0.090) \\
\end{array}$ & $\begin{array}{c}0.122 \\
(0.098) \\
\end{array}$ & $\begin{array}{c}0.264 * * * \\
(0.100) \\
\end{array}$ \\
\hline Observations & 2,069 & 13,250 & 2,069 & 2,069 & 2,069 \\
\hline $\mathrm{R}^{2}$ & 0.0123 & 0.4251 & 0.1226 & 0.0896 & 0.1033 \\
\hline Individual Controls & Yes & Yes & Yes & Yes & Yes \\
\hline Graduation Class Fixed Effects & Yes & Yes & Yes & Yes & Yes \\
\hline
\end{tabular}

Notes: * Significant at the 0.10 level, ${ }^{* *}$ Significant at the 0.05 level, ${ }^{* * *}$ Significant at the 0.01 level. Individuallevel controls include: SAT verbal, SAT math, academic composite, leadership composite, fitness score, algebra/trig placement score and indicator variables for students who are black, Hispanic, Asian, female, recruited athlete, and attended a preparatory school. For Specification 2 standard errors are clustered by student and include contemporaneous course section fixed effects.

${ }^{+}$Specification 5 excludes biological sciences. 
Table 6: Robustness Checks: Math and Science Introductory Course Professor Gender Effects Panel A. All Students

\begin{tabular}{lccc}
\hline Specification/Dependent Variable & 1 & 2 & 3 \\
\hline \hline \multirow{2}{*}{ Initial Course Performance } & $0.100^{* *}$ & $0.089^{* *}$ & $0.092^{* *}$ \\
Follow-on STEM Course Performance & $(0.045)$ & $(0.045)$ & $(0.042)$ \\
& 0.055 & 0.076 & 0.060 \\
Take Higher Level Math & $(0.061)$ & $(0.073)$ & $(0.061)$ \\
& 0.064 & 0.044 & 0.070 \\
Graduate with STEM Degree & $(0.043)$ & $(0.049)$ & $(0.044)$ \\
& 0.020 & 0.004 & 0.027 \\
& $(0.043)$ & $(0.047)$ & $(0.044)$ \\
\hline
\end{tabular}

\begin{tabular}{|c|c|c|c|}
\hline \multicolumn{4}{|l|}{ Panel B. SAT Math > 660 (median) } \\
\hline Specification/Dependent Variable & 1 & 2 & 3 \\
\hline \multirow{2}{*}{ Initial Course Performance } & $0.125^{*}$ & $0.135^{*}$ & $0.135^{* *}$ \\
\hline & $(0.071)$ & $(0.081)$ & $(0.067)$ \\
\hline \multirow{2}{*}{ Follow-on STEM Course Performance } & $0.185 * *$ & $0.187^{*}$ & $0.221 * * *$ \\
\hline & $(0.078)$ & $(0.096)$ & $(0.084)$ \\
\hline \multirow{2}{*}{ Take Higher Level Math } & $0.127 * *$ & $0.124^{*}$ & $0.038^{*}$ \\
\hline & $(0.065)$ & $(0.070)$ & $(0.073)$ \\
\hline \multirow{2}{*}{ Graduate with STEM Degree $^{+}$} & $0.143 * *$ & $0.139 * *$ & $0.150 * *$ \\
\hline & $(0.070)$ & $(0.066)$ & $(0.070)$ \\
\hline \multicolumn{4}{|l|}{ Panel C. SAT Math > 700 (75th pctile) } \\
\hline Specification/Dependent Variable & 1 & 2 & 3 \\
\hline \multirow{2}{*}{ Initial Course Performance } & $0.177 * *$ & 0.115 & $0.191 * *$ \\
\hline & $(0.079)$ & $(0.092)$ & $(0.081)$ \\
\hline \multirow{2}{*}{ Follow-on STEM Course Performance } & $0.236^{* *}$ & 0.101 & $0.271 * *$ \\
\hline & $(0.116)$ & $(0.132)$ & $(0.122)$ \\
\hline \multirow{2}{*}{ Take Higher Level Math } & $0.204^{* *}$ & $0.156^{*}$ & $0.206^{* *}$ \\
\hline & $(0.090)$ & $(0.094)$ & $(0.093)$ \\
\hline \multirow{2}{*}{ Graduate with STEM Degree $^{+}$} & $0.264 * * *$ & $0.196^{*}$ & $0.268 * * *$ \\
\hline & $(0.100)$ & $(0.104)$ & $(0.104)$ \\
\hline Individual Fixed Effect & No & No & No \\
\hline Individual Controls & Yes & No & Yes \\
\hline Individual Controls * Female Student & No & No & Yes \\
\hline
\end{tabular}

Notes: Each cell represent the coefficient for the Female Student * Female

Professor interaction variables as shown in Table 3-5. * Significant at the 0.10 level, ** Significant at the 0.05 level, $* * *$ Significant at the 0.01 level. Robust standard errors in parentheses are clustered by instructor for course performance outcomes.

${ }^{+}$Excludes biological sciences. 
Table 7: English and History Introductory Course Professor Gender Effects

\begin{tabular}{|c|c|c|c|c|c|c|}
\hline Outcome & $\begin{array}{l}\text { Initial Course } \\
\text { Performance }\end{array}$ & $\begin{array}{c}\text { Follow-on } \\
\text { Course } \\
\text { Performance }\end{array}$ & $\begin{array}{c}\text { Take Higher } \\
\text { Level } \\
\text { Humanities }\end{array}$ & $\begin{array}{c}\text { Graduate with } \\
\text { Humanities } \\
\text { Degree }\end{array}$ & $\begin{array}{l}\text { Take Higher } \\
\text { Level Math }\end{array}$ & $\begin{array}{c}\text { Graduate with } \\
\text { STEM } \\
\text { Degree }^{+}\end{array}$ \\
\hline Panel A. All Students & 1 & 2 & 3 & 4 & 5 & 6 \\
\hline $\begin{array}{l}\text { Proportion of Professors Female } \\
\text { (Introductory Courses) }\end{array}$ & $\begin{array}{l}-0.128^{*} \\
(0.071)\end{array}$ & $\begin{array}{l}-0.038 \\
(0.029)\end{array}$ & $\begin{array}{l}-0.008 \\
(0.008)\end{array}$ & $\begin{array}{l}-0.008 \\
(0.026)\end{array}$ & $\begin{array}{c}0.015 \\
(0.044)\end{array}$ & $\begin{array}{c}-0.008 \\
(0.019)\end{array}$ \\
\hline Female Student & $\begin{array}{l}-0.018 \\
(0.037)\end{array}$ & $\begin{array}{c}0.020 \\
(0.047)\end{array}$ & $\begin{array}{c}0.019 \\
(0.013)\end{array}$ & $\begin{array}{c}0.019^{* *} \\
(0.009)\end{array}$ & $\begin{array}{c}-0.109^{* * *} \\
(0.014)\end{array}$ & $\begin{array}{c}-0.123^{* * *} \\
(0.015)\end{array}$ \\
\hline $\begin{array}{l}\text { Female Student * Proportion of Professors } \\
\text { Female }\end{array}$ & $\begin{array}{c}0.029 \\
(0.073) \\
\end{array}$ & $\begin{array}{c}0.013 \\
(0.112)\end{array}$ & $\begin{array}{c}0.025 \\
(0.041)\end{array}$ & $\begin{array}{c}0.002 \\
(0.017) \\
\end{array}$ & $\begin{array}{l}-0.086^{*} \\
(0.044) \\
\end{array}$ & $\begin{array}{l}-0.035 \\
(0.044) \\
\end{array}$ \\
\hline $\begin{array}{l}\text { Observations } \\
\mathrm{R}^{2}\end{array}$ & $\begin{array}{l}15,132 \\
0.1741 \\
\end{array}$ & $\begin{array}{l}13,745 \\
0.2874\end{array}$ & $\begin{array}{c}8,943 \\
0.0621 \\
\end{array}$ & $\begin{array}{c}8,943 \\
0.0276 \\
\end{array}$ & $\begin{array}{c}8,943 \\
0.2436 \\
\end{array}$ & $\begin{array}{c}8,943 \\
0.1849 \\
\end{array}$ \\
\hline Panel B. SAT Math > 660 (Median) & 1 & 2 & 3 & 4 & 5 & 6 \\
\hline $\begin{array}{l}\text { Proportion of Professors Female } \\
\text { (Introductory Courses) }\end{array}$ & $\begin{array}{l}-0.127^{*} \\
(0.071)\end{array}$ & $\begin{array}{l}-0.031 \\
(0.036)\end{array}$ & $\begin{array}{c}0.001 \\
(0.022)\end{array}$ & $\begin{array}{l}-0.009 \\
(0.015)\end{array}$ & $\begin{array}{l}-0.013 \\
(0.027)\end{array}$ & $\begin{array}{c}0.026 \\
(0.029)\end{array}$ \\
\hline Female Student & $\begin{array}{c}0.053 \\
(0.046)\end{array}$ & $\begin{array}{c}0.043 \\
(0.054)\end{array}$ & $\begin{array}{c}0.008 \\
(0.019)\end{array}$ & $\begin{array}{c}0.018 \\
(0.012)\end{array}$ & $\begin{array}{c}-0.133 * * * \\
(0.023)\end{array}$ & $\begin{array}{c}-0.146^{* * *} \\
(0.024)\end{array}$ \\
\hline $\begin{array}{l}\text { Female Student * Proportion of Professors } \\
\text { Female }\end{array}$ & $\begin{array}{c}0.079 \\
(0.083)\end{array}$ & $\begin{array}{c}0.085 \\
(0.121)\end{array}$ & $\begin{array}{c}0.046 \\
(0.057)\end{array}$ & $\begin{array}{l}-0.022 \\
(0.037)\end{array}$ & $\begin{array}{l}-0.040 \\
(0.069)\end{array}$ & $\begin{array}{c}0.009 \\
(0.073) \\
\end{array}$ \\
\hline Observations & 6,998 & 6,441 & 4,252 & 4,252 & 4,252 & 4,252 \\
\hline$\underline{\mathrm{R}^{2}}$ & 0.1948 & 0.3458 & 0.0351 & 0.0225 & 0.1439 & 0.1158 \\
\hline $\begin{array}{l}\text { Panel C. SAT Math > } 700 \text { (75th pctile) } \\
\end{array}$ & 1 & 2 & 3 & 4 & 5 & 6 \\
\hline $\begin{array}{l}\text { Proportion of Professors Female } \\
\text { (Introductory Courses) }\end{array}$ & $\begin{array}{l}-0.106 \\
(0.102)\end{array}$ & $\begin{array}{c}0.007 \\
(0.053)\end{array}$ & $\begin{array}{l}-0.002 \\
(0.029)\end{array}$ & $\begin{array}{l}-0.006 \\
(0.018)\end{array}$ & $\begin{array}{l}-0.010 \\
(0.036)\end{array}$ & $\begin{array}{c}-0.027 \\
(0.040)\end{array}$ \\
\hline Female Student & $\begin{array}{c}0.028 \\
(0.053)\end{array}$ & $\begin{array}{c}0.049 \\
(0.075)\end{array}$ & $\begin{array}{c}0.003 \\
(0.026)\end{array}$ & $\begin{array}{l}-0.001 \\
(0.016)\end{array}$ & $\begin{array}{c}-0.174 * * * \\
(0.032)\end{array}$ & $\begin{array}{c}-0.205^{* * *} \\
(0.036)\end{array}$ \\
\hline $\begin{array}{l}\text { Female Student * Proportion of Professors } \\
\text { Female }\end{array}$ & $\begin{array}{c}0.075 \\
(0.103) \\
\end{array}$ & $\begin{array}{c}0.185 \\
(0.152) \\
\end{array}$ & $\begin{array}{c}0.104 \\
(0.077) \\
\end{array}$ & $\begin{array}{c}0.045 \\
(0.046) \\
\end{array}$ & $\begin{array}{l}-0.021 \\
(0.094) \\
\end{array}$ & $\begin{array}{c}0.060 \\
(0.106) \\
\end{array}$ \\
\hline Observations & 3,407 & 3,165 & 2,106 & 2,106 & 2,106 & 2,106 \\
\hline $\mathrm{R}^{2}$ & 0.2226 & 0.4661 & 0.0343 & 0.0171 & 0.1154 & 0.0992 \\
\hline Individual Fixed Effects & No & No & No & No & No & No \\
\hline Individual Controls & Yes & Yes & Yes & Yes & Yes & Yes \\
\hline
\end{tabular}

Notes: * Significant at the 0.10 level, ** Significant at the 0.05 level, ${ }^{* * *}$ Significant at the 0.01 level. For Specifications in column $1 \& 2$ the proportion female professor variable is an indicator for whether the professor is in the course is female. Columns $1 \& 2$ control for the academic rank of the professor. Individual-level controls include: SAT verbal, SAT math, academic composite, leadership composite, fitness score, algebra/trig placement score and indicator variables for students who are black, Hispanic, Asian, female, recruited athlete, and attended a preparatory school.

${ }^{+}$Excludes biological sciences. 
Table 8: Math and Science Introductory Course Professor Value-Added Effects by Student Gender

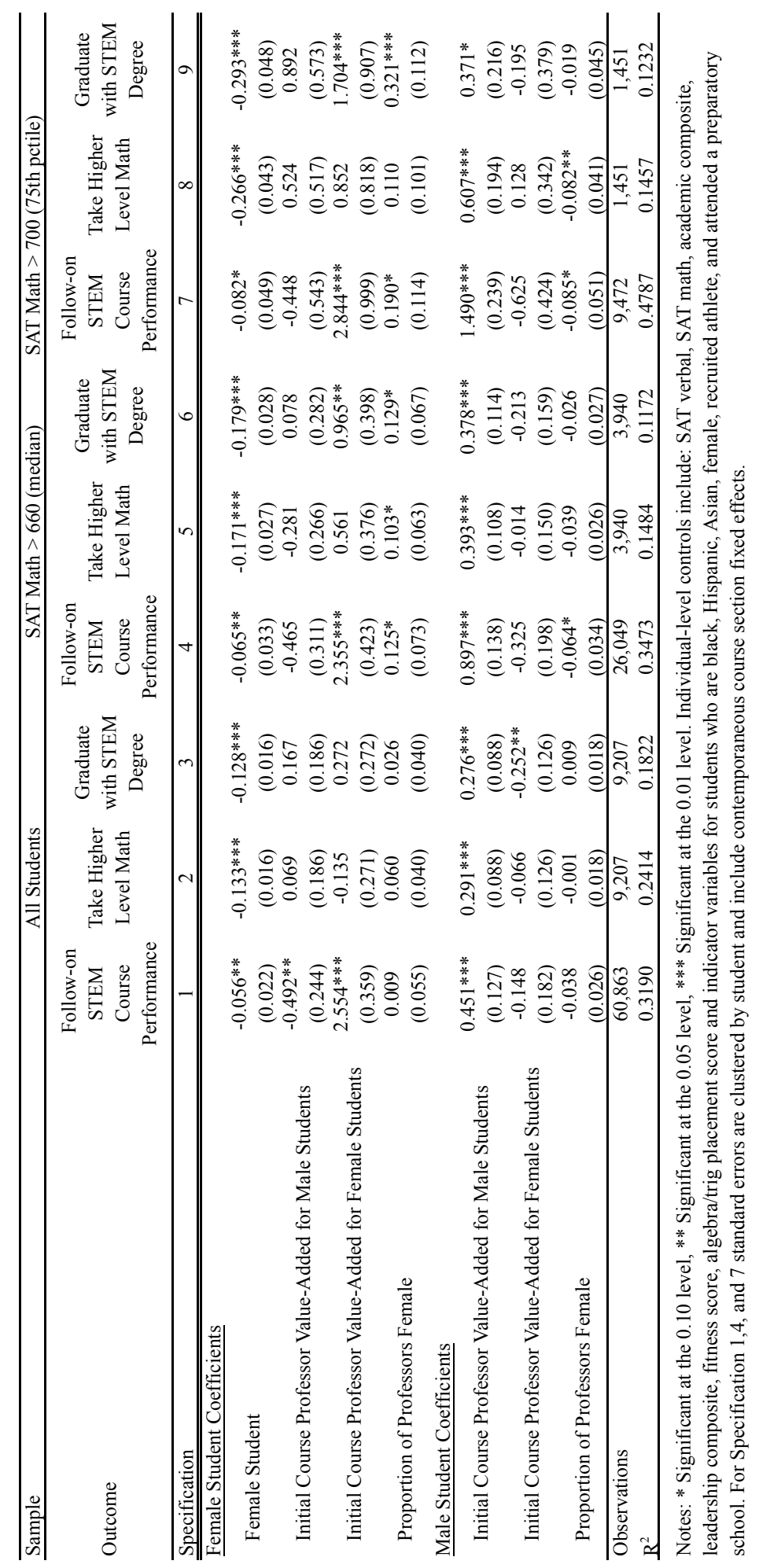


Table 9: Math and Science Follow-on Course Professor Gender Effects on Subsequent Course Taking and Choice of Major

\begin{tabular}{|c|c|c|c|}
\hline \multicolumn{4}{|l|}{ Panel A. All Students } \\
\hline Specification & 1 & 2 & 3 \\
\hline \multirow{2}{*}{ Outcome } & \multirow{2}{*}{ Grade in Course } & Take Higher & Graduate with \\
\hline & & Level Math & STEM Degree $^{+}$ \\
\hline \multirow{2}{*}{ Female Professor } & 0.020 & 0.015 & 0.006 \\
\hline & $(0.030)$ & $(0.007)$ & $(0.009)$ \\
\hline \multirow{2}{*}{ Female Student } & $-0.057 * * *$ & $-0.128 * * *$ & $-0.130 * * *$ \\
\hline & $(0.022)$ & $(0.011)$ & $(0.009)$ \\
\hline \multirow{2}{*}{ Female Student * Female Professor } & 0.011 & -0.004 & -0.010 \\
\hline & $(0.041)$ & $(0.019)$ & $(0.018)$ \\
\hline Observations & 20,952 & 20,952 & 20,952 \\
\hline $\mathrm{R}^{2}$ & 0.2528 & 0.2316 & 0.1860 \\
\hline \multicolumn{4}{|l|}{ Panel B. SAT Math > 660 (median) } \\
\hline Specification & 1 & 2 & 3 \\
\hline \multirow{2}{*}{ Outcome } & \multirow{2}{*}{ Grade in Course } & Take Higher & Graduate with \\
\hline & & Level Math & STEM Degree $^{+}$ \\
\hline \multirow{2}{*}{ Female Professor } & 0.024 & 0.009 & -0.0001 \\
\hline & $(0.032)$ & $(0.011)$ & $(0.014)$ \\
\hline \multirow{2}{*}{ Female Student } & $-0.088 * *$ & $-0.134 * * *$ & $-0146 * * *$ \\
\hline & $(0.034)$ & $(0.019)$ & $(0.016)$ \\
\hline \multirow{2}{*}{ Female Student * Female Professor } & 0.077 & -0.011 & -0.022 \\
\hline & $(0.064)$ & $(0.044)$ & $(0.041)$ \\
\hline Observations & 8,759 & 8,759 & 8,759 \\
\hline $\mathrm{R}^{2}$ & 0.2334 & 0.1589 & 0.1372 \\
\hline \multicolumn{4}{|l|}{ Panel C. SAT Math > 700 (75th pctile) } \\
\hline Specification & 1 & 2 & 3 \\
\hline \multirow{2}{*}{ Outcome } & \multirow{2}{*}{ Grade in Course } & Take Higher & Graduate with \\
\hline & & Level Math & STEM Degree $^{+}$ \\
\hline \multirow{2}{*}{ Female Professor } & 0.016 & -0.002 & -0.013 \\
\hline & $(0.037)$ & $(0.015)$ & $(0.018)$ \\
\hline \multirow{2}{*}{ Female Student } & $-0.095 * *$ & $-0.198 * * *$ & $-0.208 * * *$ \\
\hline & $(0.048)$ & $(0.029)$ & $(0.028)$ \\
\hline \multirow{2}{*}{ Female Student * Female Professor } & -0.001 & -0.017 & -0.062 \\
\hline & $(0.077)$ & $(0.044)$ & $(0.046)$ \\
\hline Observations & 3,951 & 3,951 & 3,951 \\
\hline $\mathrm{R}^{2}$ & 0.2349 & 0.1539 & 0.1436 \\
\hline Individual Fixed Effect & No & No & No \\
\hline Individual Controls & Yes & Yes & Yes \\
\hline Course by Semester Fixed Effects & Yes & Yes & Yes \\
\hline Graduation Class Fixed Effects & Yes & Yes & Yes \\
\hline Time of Day Dummies & Yes & Yes & Yes \\
\hline
\end{tabular}

Notes: * Significant at the 0.10 level, $* *$ Significant at the 0.05 level, $* * *$ Significant at the

0.01 level. Robust standard errors in parentheses are clustered by instructor. All

specifications control for the academic rank of the professor. Individual-level controls

include: SAT verbal, SAT math, academic composite, leadership composite, fitness score, algebra/trig placement score and indicator variables for students who are black, Hispanic, Asian, female, recruited athlete, and attended a preparatory school.

${ }^{+}$Excludes biological sciences. 